\title{
Diverse and Productive Source of Biopolymer Inspiration: Marine Collagens
}

\author{
Dario Fassini, Iain C. Wilkie, Marina Pozzolini, Cinzia Ferrario, Michela Sugni, Miguel S. Rocha, \\ Marco Giovine, Francesco Bonasoro, Tiago H. Silva,* and Rui L. Reis
}

Cite This: https://doi.org/10.1021/acs.biomac.1c00013

Read Online

ABSTRACT: Marine biodiversity is expressed through the huge variety of vertebrate and invertebrate species inhabiting intertidal to deep-sea environments. The extraordinary variety of "forms and functions" exhibited by marine animals suggests they are a promising source of bioactive molecules and provides potential inspiration for different biomimetic approaches. This diversity is familiar to biologists and has led to intensive investigation of metabolites, polysaccharides, and other compounds. However, marine collagens are less well-known. This review will provide detailed insight into the diversity of collagens present in marine species in terms of their genetics, structure, properties, and physiology. In the last part of the review the focus will be on the most common marine collagen sources and on the latest advances in the development of innovative materials exploiting, or inspired by, marine collagens.

\section{INTRODUCTION}

According to recent estimates there are 7.7 million animal species on the Earth; of these, around 2.1 million inhabit marine environments. ${ }^{1}$ Although there is no doubt that terrestrial ecosystems are both richer and better known in terms of numbers of species, the scenario is reversed when higher taxonomic levels are taken into account, ${ }^{1,2}$ possibly due to the greater stability of the aquatic environments during their evolutionary histories. This is also demonstrated by the wide variety of morphologies and physiologies shown by aquatic species and by the wide range of metabolites that are a valuable source of bioactive compounds with biomedical applications. $^{3-5}$

Animals appeared and mostly evolved in water; one of the key factors that led to the passage from small cell aggregates to a variety of large animals is thought to be the appearance of a relatively simple but highly hierarchical protein: collagen., Besides being a key molecule in the life histories and evolution of more complex life forms, collagen also represents a valuable compound for different biotechnological fields.

Collagens, in particular marine collagens, have recently attracted the attention of scientists, as demonstrated by the increasing number of publications in the last 15 years. ${ }^{8}$ Marine collagens and collagen-derived products, such as gelatin and collagen peptides, have shown interesting properties in comparison with the more traditional and established sources (mainly bovine and porcine). Most of the investigations of marine collagens have dealt with those derived from vertebrates, whereas invertebrates have been quite neglected as a source of these molecules.

This review will give an overview of the general characteristics of collagens before examining the main sources of marine collagens, the main applications for these collagens, and the main challenges and future opportunities that might be encountered during a deeper exploration of marine collagens.

\section{COLLAGEN FUNDAMENTALS}

Collagens are a large family of proteins that form the main organic portion of the extracellular matrix (ECM). Collagens, with the possible exceptions represented by Placozoa ${ }^{9}$ and Rotifera, ${ }^{10}$ are often considered to be a metazoan hallmark, ${ }^{11}$ and their appearance led to the creation of an extracellular scaffolding that allowed the transition from microscopic protozoans to the macroscopic multicellular complexity of metazoans. ${ }^{6}$ Collagens are highly hierarchical proteins, and by forming fibrils, microfibrillar networks, and basement membranes, they represent the most abundant proteins in many

Received: January 6, 2021

Revised: March 26, 2021 
animals and the main building blocks of most connective tissues and organs.

Collagen is particularly abundant in connective tissues where its main functions are to transmit, resist, and dissipate mechanical forces and to store and release elastic strain energy. ${ }^{12}$ As well as forming well-organized structures that contribute to the cellular scaffolding and confer mechanical stability on tissues and organs, collagens also present specific binding domains that have many important functions in different physiological processes. Through the presence of molecule-binding motifs, collagens are involved in the storage and release of cellular mediators, thus playing a critical role during development and during the repair and regeneration of tissues and organs. ${ }^{13-16}$ One well-known binding site is the RGD motif, which binds fibronectin. ${ }^{17}$

So far almost 30 types of collagen have been described. ${ }^{11}$ All of them have repeated Gly-Xaa-Yaa tripeptide sequences (where Xaa and Yaa are most commonly proline and hydroxyproline, respectively, but can be any amino acid), which are mainly responsible for the presence of the $\alpha$ helix domain. ${ }^{8}$

2.1. Collagen Synthesis. As is the case with all proteins, collagen synthesis starts with DNA transcription following specific signals (Figure 1).

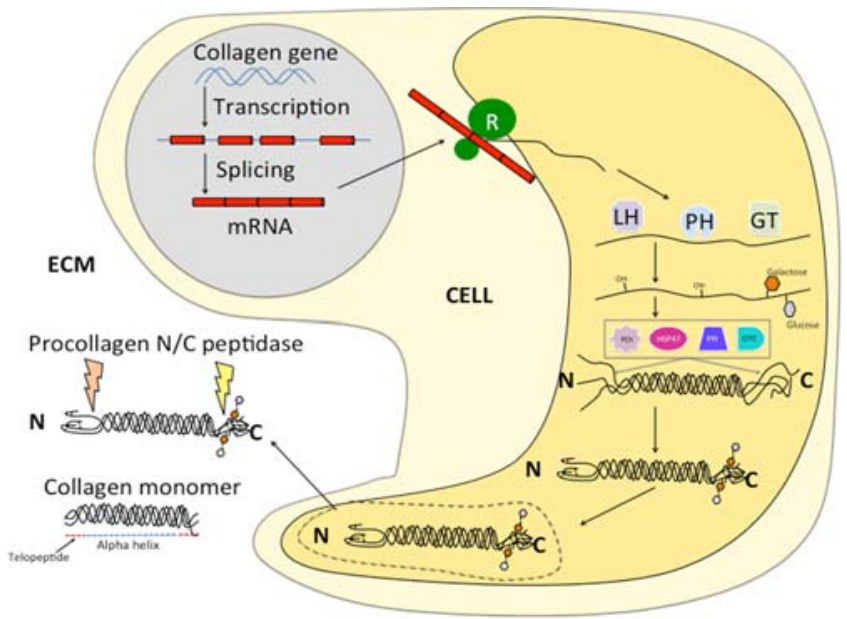

Figure 1. Graphical representation of the collagen synthesis and secretion pathway. GT, hydroxylysyl galactosyltransferase/galactosylhydroxylysyl glucosyltransferase; LH, lysin hydroxylase; HSP 47, heat shock protein 47; OTC, oligosaccharyl transferase complex; PDI, protein disulfide isomerase; $\mathrm{PH}$, proline hydroxylase; PPI, peptidylprolyl cis-trans-isomerase; $\mathrm{R}$, ribosome. Adapted from Advanced Drug Delivery Reviews, 55 (12), Gelse, K., Pöschl, E., Aigner, T., Collagens - Structure, Function, and Biosynthesis, 1531-1546, Copyright 2003, with permission from Elsevier.

After gene translation and eventual alternative splicing events, the peptide sequences are produced by the ribosomes and processed by the RER/Golgi where post-transcriptional modifications take place. Gene translation and alternative splicing depend largely on cell phenotype and physiological state: different cytokines and growth factors are involved in the regulation of collagen production. ${ }^{18}$ The variety of collagens that can be produced by a single gene is dramatically enhanced by the numerous post-transcriptional modifications produced by a toolkit of specific enzymes (see Table 1).

Once the procollagen molecules (collagen precursor) are folded, they are secreted into the extracellular matrix (ECM) where, depending on the collagen type, the $\mathrm{N}$ - and $\mathrm{C}$ propeptides can be removed by procollagen $\mathrm{N}$ - and procollagen C-proteinase. ${ }^{21}$ Once in the ECM, collagens undergo a spontaneous process of high-order alignment that is characteristic for each collagen subfamily (structural organization is detailed in section 2.2).

After collagens have been released and have acquired their conformation in the ECM, they undergo a set of modifications. The nature of these modifications depends largely on the degree of quantitative and qualitative post-translational modifications, the tissue where they are secreted, and the age of the individual (see ref 22 for an extensive review of collagen maturation and modifications). The modifications can be divided roughly into two different categories: those that crosslink procollagen with divalent bonds and those that modify mature collagen via trivalent cross-links and glycation.

The end-overlap quarter-staggered alignment, typical of fibril-forming collagen types I and III, is promoted by the specific divalent cross-linking of residues in the telopeptides (9N and 16C) and in the helical region (residues 87 and 930). In the helical region the sites involved have the specific amino acid sequence Hyl-Gly-His-Arg-Gly. ${ }^{22}$ The aldehyde groups formed in the telopeptide sites can react with the hydroxylysine in this sequence of the helix due to the staggering of the molecules, thus contributing to the stabilization of the structure. In the network-forming collagen type IV, the sequence is slightly different, with the His being substituted by $\mathrm{Glu}^{22}$ here, the cross-links occur at the $7 \mathrm{~S} \mathrm{~N}$-terminal region of adjacent molecules, while cross-linking between two consecutive type IV collagen molecules is provided by stable disulfide bonds. $^{23}$

The process of collagen maturation also involves further intra-/intermolecular cross-linking and is responsible for the increasing insolubility and mechanical strength of older collagenous tissues. The process depends on several different reactions between amino acidic groups as well as on glycation processes that have important consequences for collagen structure and properties (see ref 22 for an extensive and detailed review).

2.2. Collagen Types and Microstructures. As discussed above, all collagens are characterized by the presence of a specific region where three polypeptide chains self-assemble to form a tightly bonded triple helix structure. The presence of these regions is due to the strong tendency for proline-rich repeated Gly-Xaa-Yaa tripeptide sequences to assume this conformation (see for instance ref 24 for a detailed explanation of the chemical bonds involved).

Collagens can be classified according to the different supramolecular aggregations formed by the aforementioned triple helices. According to Bailey and co-workers ${ }^{22}$ collagen assembly results in the formation of fibril-forming collagens, fibril-associated collagens with interrupted triple helices (FACIT), network-forming collagens, anchoring fibrils, transmembrane collagens, basement membrane collagens, and others with unique functions (see also ref 24).

Types I, II, and III are the most common fibrous collagens. They are long rodlike proteins that self-assemble in a parallel, quarter-staggered end-overlap arrangement to form fibrils. This staggered organization produces a characteristic banding pattern with a periodicity of approximately $67 \mathrm{~nm}$, although small variations have been found. ${ }^{25}$ Other less common collagens belonging to this category are types $\mathrm{V}$ and $\mathrm{XI}$ which 
Table 1. Enzymes Involved in the Synthesis of Collagens and Its Post-transcriptional Modifications ${ }^{a}$

\begin{tabular}{|c|c|c|c|}
\hline Enzyme & $\mathrm{Abb}$ & Functions & Significance \\
\hline $\begin{array}{l}\text { Prolyl 3-hydroxylase, prolyl 4-hydroxylase, } \\
\text { lysyl hydroxylase }\end{array}$ & $\begin{array}{l}\mathrm{PH} / \\
\mathrm{LH}\end{array}$ & $\begin{array}{l}\text { Hydroxylates specific proline and lysine } \\
\text { residues }\end{array}$ & $\begin{array}{l}\text { Promote triple helix formation and stability, generate } \\
\text { attachment sites for saccharides and interfibrillar bonds }{ }^{13}\end{array}$ \\
\hline $\begin{array}{l}\text { Hydroxylysyl galactosyltransferase, } \\
\text { galactosylhydroxylysyl- } \\
\text { glucosyltransferase }\end{array}$ & GT & $\begin{array}{l}\text { Transfers glucosyl and galactosyl residues to } \\
\text { the OH- groups of hydroxylysine }\end{array}$ & Generate suitable attachment sites for saccharides ${ }^{13}$ \\
\hline Oligosaccharyl transferase complex & OTC & $\begin{array}{l}\text { Attaches saccharides to the glucosyl/ } \\
\text { galactosyl groups }\end{array}$ & $\begin{array}{l}\text { Promotes alignment of C-terminal and correct folding of } \\
\text { tropocollagen }\end{array}$ \\
\hline Protein disulfide isomerase & PDI & $\begin{array}{l}\text { Promotes disulfide bonds in the nonhelical } \\
\text { regions }\end{array}$ & PDI is involved also in interfibrillar bond formation. ${ }^{20}$ \\
\hline Peptidyl-prolyl cis-trans-isomerase & PPI & $\begin{array}{l}\text { Accelerates isomerization and protein } \\
\text { folding }\end{array}$ & \\
\hline
\end{tabular}

${ }^{a} \mathrm{Abb}$, abbreviation.

are involved in fibril initiation and have important roles in the determination of fibril structure and ECM organization. ${ }^{13,25}$

Type IV collagen is a very long $(400 \mathrm{~nm})$, flexible protein, which has irregularities in the Gly-X-Y sequence and is the main constituent of all basement membranes. All known type IV collagens have the same modular organization: a short $\mathrm{N}$ terminal domain, a central collagenous domain with multiple interruptions in the repeated Gly-Xaa-Yaa sequence providing the molecule with flexibility, ${ }^{26}$ and a highly conserved Cterminal domain (NC1). The NC1 domain consists of two hemidomains which share highly similar amino acid sequences. ${ }^{27}$ This collagen forms a "chicken-wire" network based, as mentioned above, on units of four molecules arranged in an antiparallel fashion through their amino terminuses to produce a $110 \mathrm{~nm}$ overlap region known as the $7 \mathrm{~S}$ region, while adjacent carboxy terminuses, which lack the triple helical conformation, interact to generate a characteristic planar conformation. ${ }^{11}$

Like type IV, type VIII and X short-chain collagens also form networks. Their supramolecular structure has not been fully described, but it seems that type VIII forms hexagonal lattices in Descemet's membrane of the cornea, ${ }^{28}$ while type $\mathrm{X}$ is mostly associated with growth plate cartilage. ${ }^{29}$

Type VII collagen forms short fibrils resulting from the lateral aggregation of antiparallel overlapped dimer microfibrils. It has a $60 \mathrm{~nm}$ periodicity and can be found beneath the lamina densa of many epithelia. In skin and cornea, it is an important structural component of the anchoring fibrils, forming, via type IV collagen/type VII carboxyl-terminal domain interactions, amorphous plaques that are involved in the interactions of collagen fibrils, microfibrils, and other ECM components. ${ }^{30}$

Type VI is a microfibrillar collagen that forms a loosely packed filamentous structure in all the connective tissues except bones; ${ }^{13}$ it is thought to also be involved in the alignment of large type I collagen fibers. ${ }^{22,31}$ This collagen consists of laterally aggregated beaded filaments with a peculiar banding pattern. The collagen is composed of two peptides: one has a molecular weight (MW) of $140 \mathrm{kDa}$ and constitutes the helical region; the other is a $260 \mathrm{kDa}$ protein involved in the aggregation of the fibrils through disulfide cross-links. ${ }^{32}$ The banding pattern has been found to have a periodicity of around $95 \mathrm{~nm},{ }^{32}$ although for simplicity this is generally reported as $100 \mathrm{~nm}$.

Several collagen types do not form fibrils or networks but are present among fibril-forming collagens. These include type XII and type XIV collagens associated with type I collagen. ${ }^{33,34}$ Type IX collagen is associated with type II collagen in adults ${ }^{35}$ (Figure 2), while both type XII and XIV have been detected in fetal cartilage. ${ }^{36}$

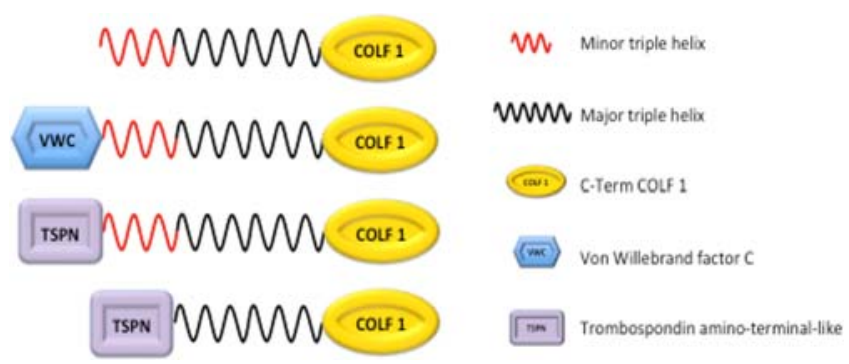

Figure 2. Scheme representing the possible collagen $\mathrm{N}$ - and Cterminal configurations of fibrillar collagens. "Fibrillar collagen characteristics" by Exposito, J.-Y. Y., Valcourt, U., Cluzel, C., Lethias, C., ref 11., published in Int. J. Mol. Sci. is licensed under CC BY-NCSA 3.0.

The structures described above are based on human collagens, which have been well described and characterized, while much less is known about the collagens of other animals. Most of the data on aquatic organisms relate to fish and very few to marine invertebrates. Marine invertebrates possess collagens that are similar to those of higher vertebrates, namely homotypic and heterotypic fibrillar collagens, ${ }^{37,38}$ basement membranes, ${ }^{39}$ and microfibrils. ${ }^{40,41}$ However, in contrast to mammalian type I and $\mathrm{V}$ collagens, which are always composed of heterotrimeric $\alpha 1 / \alpha 2$ chains, $^{13}$ collagen type $\mathrm{I}$ and $\mathrm{V}$ in marine organisms can be either homotrimeric or composed of $\alpha 1 / \alpha 2 / \alpha 3$ chains. ${ }^{42,43}$ Invertebrate fibrillar collagens are also characterized by the presence of specific imperfections in the collagenous domain. ${ }^{44}$ Moreover, examples of collagens with unique features have been described (Table 2).

2.3. Collagen Genomics and Evolution. The characterization of the collagen genes of lower metazoans has provided information on the evolution of these proteins. ${ }^{11}$ This has been facilitated by the development of next-generation DNA sequencing methods ${ }^{54}$ and the subsequent fall of the costs.

2.3.1. Origin of Fibrillar Collagen Genes. The $\alpha$-chain of fibrillar collagens has the same overall molecular architecture in all metazoans, consisting of a variable $\mathrm{N}$-propeptide region, a major triple helical portion, and a terminal C-propeptide that includes the characteristic COLF1 domain. In mammals, as shown in Figure 2, four main $\mathrm{N}$-propeptide configurations have been described: a minor triple helix only; a minor triple helix followed by a von Willebrand factor-type C domain (VWC); a thrombospondin amino-terminal-like domain (TSPN); and a TSPN module only.

In Porifera, the $\alpha$-chains at the $\mathrm{N}$-propeptide exhibit only the two last configuration types; the $\alpha$-chain of cnidarians possesses a specific whey acid protein (WAP) module, or 
Table 2. Collagens with Unique Features from Marine Invertebrates

\begin{tabular}{|c|c|c|c|}
\hline Phylum & Type(s) & Special features & Localization \\
\hline Porifera & I-like & $\begin{array}{l}\text { Long and thin fibrils; }{ }^{45} \text { labile and reversible interfibrillar cross-links; }{ }^{46} \text { Gly-3HPro-4Hpro tripeptides } \\
\text { involved in mineralization }{ }^{47}\end{array}$ & mesohyl \\
\hline Cnidaria & $\begin{array}{l}\text { I-like } \\
\text { minicollagens }\end{array}$ & High elastic properties; ${ }^{48}$ very short and resistant collagen molecules ${ }^{49}$ & $\begin{array}{l}\text { Mesogloea } \\
\text { cnidocysts }\end{array}$ \\
\hline Annelida & Type III-like & High denaturation temperature; ${ }^{50}$ very long fibrils ${ }^{51}$ & cuticle \\
\hline Mollusca & n.a. & Presence of silk-like domains ${ }^{52}$ & distal byssus \\
\hline Echinodermata & I-like & Long fibrils; ${ }^{53}$ labile, reversible and irreversible interfibrillar cross-links ${ }^{12}$ & $\begin{array}{l}\text { mutable } \\
\text { collagenous } \\
\text { structures }\end{array}$ \\
\hline
\end{tabular}

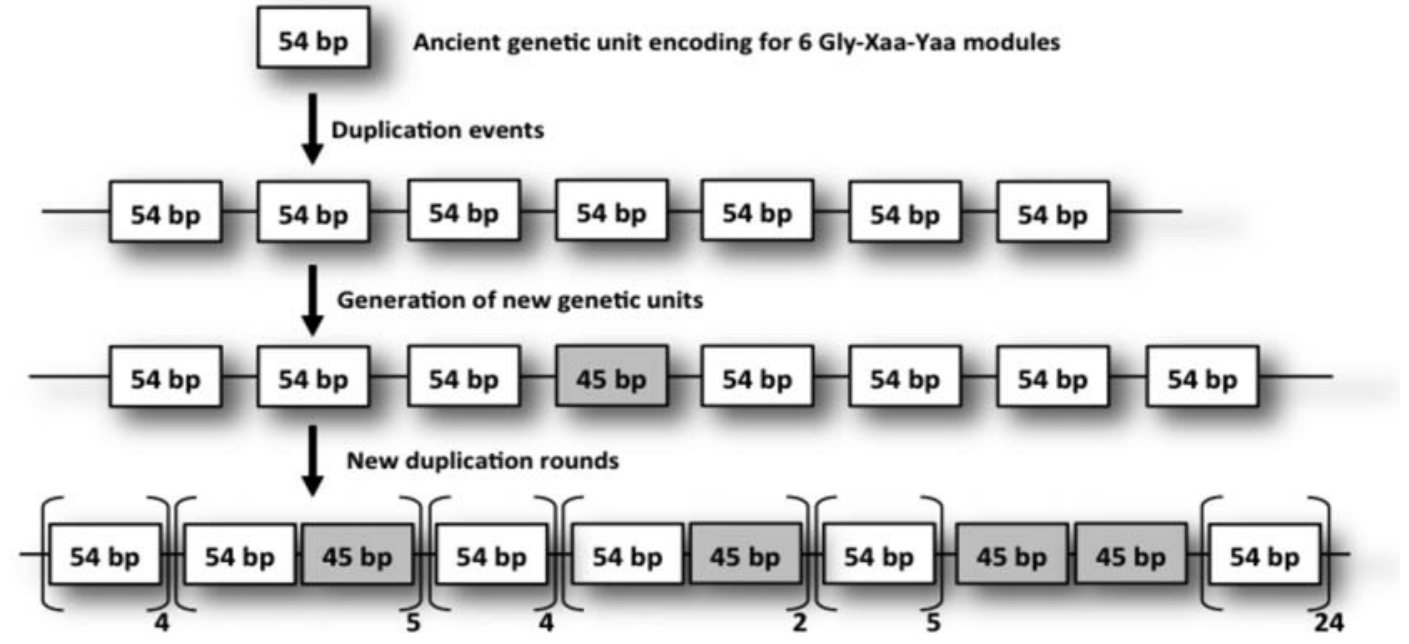

Figure 3. Schematic representation of the origin of the first ancestral fibrillar collagen. The gene originated by two rounds of duplications: after a first multiple duplication event of a $54 \mathrm{bp}$ unit, an unequal crossing over brought the introduction of a new 45 bp exon; finally, a new multiple duplication event brought the first collagen gene structure.

WAP and von Willebrand A domain (VWA), in addition to a minor triple helix in their N-propeptide. ${ }^{55}$ Molluscs are the first group of marine invertebrates in which a VWC domain at the $\mathrm{N}$-terminal propeptide has been found. In echinoderms, particularly in some sea urchins, a four-cysteine region (sea urchin fibrillar module: SURF) is placed between the VWC domain and the minor triple helix. ${ }^{11,56}$

At the genomic level the major triple helix region of fibrillar collagen genes consists of exons that are $54 \mathrm{bp}$ in length or multiples of $54 \mathrm{bp}$ or of $54 \mathrm{bp}$ minus $9 \mathrm{bp}^{11}$ each exon starts with a complete glycine codon and ends with an intact Yaa codon. The identification of the first fibrillar collagen gene in the sponge Ephydatia mülleri ${ }^{57}$ and the comparison of its exon/ intron organization with that of mammalian fibrillar collagen genes suggested a model of the exon/intron organization of an ancestral fibrillar collagen gene (Figure 3).

Vertebrate fibrillar collagens have been divided into three clades based on ultrastructural and genetic data: (i) A clade, including types I-III and the pro- $\alpha 2(\mathrm{~V})$ chain; (ii) B clade, with pro- $\alpha 1(\mathrm{~V})$, pro- $\alpha 3(\mathrm{~V})$, pro- $\alpha 1(\mathrm{XI})$, and pro- $\alpha 2(\mathrm{XI})$ chains; (iii) C clade, including type XXIV and XXVIII collagen chains. ${ }^{11}$ This division, mainly based on the major triple helix region, reflects also the $\mathrm{N}$-terminal pro-peptide features; A clade members, except pro- $\alpha 2$ (I), have a VWC module, while $\mathrm{B}$ and $\mathrm{C}$ clade members possess a TSPN domain. Through a combination of multiple alignments of major triple helices and a comparative analysis of exon-intron structure, it has been revealed that the three fibrillar collagen clades of vertebrates arose before the emergence of chordates, while the divergence between ancestral $\mathrm{A}$ and $\mathrm{B} / \mathrm{C}$ clade chains occurred very early during metazoan evolution, before the divergence of the poriferan and the eumetazoan lineages. ${ }^{11,55}$ These analyses also indicated that $\mathrm{B}$ clade preserves the characteristic modular structure present in higher metazoans, from sponges to humans. The vertebrate $\alpha$-chains present in this clade are type V and XI. Since these collagen types are considered essential for early fibril formation and fibril diameter regulation, ${ }^{58}$ the high degree of conservation of the modular organization of members of the B clade highlights their functional importance. The sequencing of lower invertebrate genomes has revealed that the number of predicted fibrillar collagen sequences is greater in Porifera and Cnidaria than in some protostomes (molluscs and annelids) and in the chordate Ciona intestinalis.

2.3.2. Origin of Type IV Collagen and Spongin ShortChain Collagen Genes. As stated above, type IV collagen has been found in all major lower metazoan groups. While in vertebrates six genes coding for type IV $\alpha$-chains have been identified, ${ }^{59}$ only two gene copies have been identified so far among most invertebrates as Cnidaria and Placozoa. ${ }^{60}$ The greater number of type IV gene copies in vertebrates than in invertebrates may be explained by a duplication event occurring before the divergence of the higher phyla. However, a recent study conducted on more than ten different species of Ctenophora reveals that in this ancient phylum up to 20 collagen type IV genes are present. ${ }^{60}$

In some demosponge poriferans a family of short nonfibrillar collagen types has been identified, ${ }^{61,62}$ which are characterized by a collagenous domain formed by approximately 120 GlyXaa-Yaa triplets provided with some interruptions and a C- 
terminal noncollagenous $\mathrm{NC1}$ region with similarities to those of nematode cuticular collagen and the type IV collagen family. ${ }^{63}$ These molecules have not been detected in vertebrates, and many authors consider them constituents of spongin, which is a component of the demosponge exoskeleton and is involved in attachment to the substratum. Phylogenetic studies and structural modeling analyses have resulted in a model for the evolution of spongin short-chain collagen/type IV collagen NC1 domains, which suggests that the ancestral spongin short-chain collagen--related/type IV collagen gene duplicated at a stage prior to the common ancestor of the Bilateria to produce daughter genes that evolved separately.

To date, the exact and complete molecular composition of the spongin in Demospongiae is still unclear due to the great biodiversity of this class, and its elucidation represents a real challenge for the future. Some authors are skeptical about the collagenous nature of spongin, especially with regard to the keratose group included in the common bath sponges. ${ }^{64}$ On the basis of the amino acid percentage composition, the low glycine content suggests the existence of noncollagenous spongin-specific proteins containing halogen groups. Anyway, although the existence of some specific-spongin proteins cannot be excluded due to the reduced size of the collagenous domain compared to the noncollagenous $\mathrm{N}$ and $\mathrm{C}$ regions, it is not possible to exclude the presence of the short nonfibrillar type IV-related collagens in the spongin composition. In conclusion, only a careful proteomic analysis of spongin will be able to clear up any confusion on this issue concerning a biomaterial that has considerable biotechnological potential. For a comprehensive analysis of the potential of spongin as a natural 3D biomaterial consult ref 65 .

2.4. Mechanically Adaptable Collagenous Tissues. 2.4.1. Background. The mechanical properties of collagenous tissues are generally stable within physiological time scales, although they may change slowly during maturation and aging and in response to long-term shifts in the patterns of force to which they are subjected. ${ }^{66,67} \mathrm{~A}$ few exceptions are found in mammals during early developmental stages ${ }^{68}$ and pregnancy ${ }^{69}$ when significant changes in mechanical properties occur with time scales of hours to days. These events result from changes in microstructural organization, biochemical composition, and collagen cross-linking due to modification of the synthetic activity of the stromal cells and of matrix metalloproteinase (MMP) activity in the ECM. ${ }^{70-72}$ However, in nature there are examples of peculiar mechanically adaptable collagenous tissues that can rapidly (seconds to minutes) and reversibly change their mechanical properties through adjustment of the interactions between collagen fibrils; these are found in members of the phylum Echinodermata.

2.4.2. Mutable Collagenous Tissues of Echinoderms. At present the mutable collagenous tissues (MCTs) of echinoderms are the best-characterized examples of "dynamic" connective tissues, and their biochemistry, ultrastructure, physiology, and biomechanics have been intensively investigated. $^{73-81}$

MCTs can undergo extreme changes in their passive mechanical properties, switching between stiff and compliant conditions within a time scale of less than $1 \mathrm{~s}$ to a few minutes. This phenomenon, called "variable tensility" or "mutability", relies completely on changes in the cohesive forces between adjacent collagen fibrils rather than changes in the fibrils themselves, and it is strictly regulated by the nervous system. This mechanism has been recently confirmed at the nanoscale level by synchrotron small-angle X-ray diffraction, during in situ testing. ${ }^{79}$ This provided, for the first time, a direct view of the phenomenon, particularly of the ultrastructural and mechanical changes as they occur in real time.

MCTs occur in all echinoderm classes, are present at different anatomical locations (dermis, ligaments, etc.), and play a key role in different aspects of echinoderm biology including autotomy, asexual reproduction, and energy-sparing postural control. ${ }^{12}$ As such, they are considered a distinctive feature of this animal phylum.

Each MCT structure can exhibit one of three patterns of change in its passive tensile properties: reversible changes alone; irreversible destabilization alone; and both reversible changes and irreversible destabilization. ${ }^{12,82}$ Certain MCT structures can also generate tensile force: in some cases, this might be partially ascribed to the presence of fine muscle fibers distributed between the bundles of collagen fibrils, but where there are no muscle fibers, as in the cirral, stalk, and brachial ligaments of crinoids, this hypothesis can be firmly excluded. ${ }^{83-85}$

From a structural point of view, the extracellular matrix of almost all mutable collagenous structures is dominated by assemblages of spindle-shaped collagen fibrils, which exhibit a morphological variability comparable to that shown by vertebrate connective tissue structures. ${ }^{86-88}$ The spindle-like shape of the fibrils modulates the stress uptake through a uniform distribution of stress throughout the fibril. ${ }^{89}$ FT-IR and confocal Raman microscopy analyses indicated that MCTs are mainly composed of collagen fibrils structurally similar to mammalian type I collagen, although other types of collagen are probably also present in the tissue. ${ }^{81}$ This is consistent with what normally is found in most mammalian connective tissues where heterotypic collagen fibrils are frequently found in the dermis, cornea, and ligaments. ${ }^{24}$ Molecular data on gene sequences and gene organization indicate that at least some echinoderm collagen polypeptides are evolutionarily close to those of vertebrate fibrillar collagens, ${ }^{11}$ although homologies are relatively low $\left(35-60 \%^{77}\right)$.

The mechanical properties of single collagen fibrils from a sea cucumber have been characterized; these indicate that the fibrils contribute to the fast viscoelastic behavior of MCTs, with other tissue components providing the longer-duration viscous behavior and relaxation time. ${ }^{90,91}$

In both mutable and nonmutable collagenous structures of echinoderms, collagen fibril bundles are delimited by loose networks of hollow microfibrils $10-14 \mathrm{~nm}$ in diameter. ${ }^{41}$ These can be aggregated into fibers or sheets but most often form loose sheaths around bundles of collagen fibrils. They resemble the fibrillin-containing microfibrils of mammalian connective tissue and may confer elasticity on MCTs, ${ }^{40,92}$ thus promoting the recovery of the tissue to its original restingcondition dimensions following deformation. ${ }^{12}$ There is no evidence that they are directly involved in the variable tensility of MCTs.

Proteoglycans (PGs) and other glycosaminoglycan (GAG)containing molecules are present on the surface of the collagen fibrils and may have a role in variable tensility by acting as binding sites for the effector molecules responsible for interfibrillar cohesion. $^{12}$

Potential effector molecules that are involved in the regulation of MCT tensility include the proteins stiparin and tensilin, the fibril-aggregating activities of which are modified by a variety of specific inhibitors. Trotter and co-workers ${ }^{93}$ 
demonstrated that stiparin, the most abundant soluble glycoprotein in the dermis of the holothurian Cucumaria frondosa, causes in vitro calcium-independent aggregation of collagen fibrils but has no effect on the mechanical properties of the intact dermis. ${ }^{94}$ The putative stiparin inhibitor is a 62 $\mathrm{kDa}$ sulfated glycoprotein that binds stiparin but not collagen fibrils. ${ }^{95}$ Tensilin (also known as a "stiffener") is the most extensively studied MCT effector. It has been isolated from the dermis of different sea cucumber species, and the tensilin gene of one of these has been fully sequenced. ${ }^{73,96}$ Like stiparin, tensilin causes aggregation of isolated collagen fibrils but it also stiffens the intact inner dermis, with both effects being calciumindependent. $^{94}$ Tensilin promotes limited dermal stiffening (from the "compliant" to the "standard" state ${ }^{73}$ ), whereas another molecule induces maximal stiffening (from the "standard" to the "stiff" state). ${ }^{74}$ Recently a tensilin-like gene was found in the genome of the sea urchin Strongylocentrotus purpuratus, but its relatively low homology ${ }^{97}$ and the lack of a marked stiffening effect of the recombinantly produced protein $^{78}$ suggest that the molecular mechanism underpinning MCT stiffening may not be evolutionarily conserved across the Echinodermata. Regarding MCT destiffening, softenin is a protein that increases the compliance of the holothurian body wall, possibly by inhibiting cross-bridge formation between collagen fibrils. ${ }^{98}$

It has also been suggested that MMPs have a role in the mutability phenomena, in view of the homology between tensilin and tissue inhibitors of metalloproteases (TIMPs), which are important modulators of MMPs involved in extracellular matrix remodeling in vertebrates. ${ }^{96}$ The effects of a synthetic MMP inhibitor, galardin, on the mechanical properties of sea urchin ligaments in different mechanical states provided evidence that MMP-like molecules may contribute to MCT variable tensility. ${ }^{76}$ It is well-known that one mammalian TIMP (TIMP-3) binds strongly to the extracellular matrix via a GAG-binding site, ${ }^{99}$ as does tensilin. This similarity and the involvement of MMPs and TIMPs in the mechanical changes undergone by female mammalian reproductive tract collagenous tissues indicate that the mechanism underpinning MCT mutability could have evolved from a MMP-TIMP system.

Although the mutability of echinoderms connective tissues has no equal in terms of extent and time scale, among invertebrates there are other examples of "dynamic tissues".

The body of marine sponges belonging to the class Demospongiae consists mainly of a collagenous mesohyl, which can undergo reversible changes in stiffness. ${ }^{100,101}$ This mechanical adaptability has been characterized most thoroughly in Chondrosia reniformis. ${ }^{46,101-103}$ It appears that, like echinoderms, this sponge is able to change the mechanical properties of its connective tissue (between standard, compliant, and stiff states) by actively modulating collagen fibril interactions. ${ }^{46,101,103}$ It has been observed that changes in the mechanical state are not accompanied by changes in collagen fibril morphology but that fibrils are packed more loosely when the mesohyl is in a compliant state and more densely in the stiff state. ${ }^{104,105}$ Both stiffening and destiffening are under cellular control, with at least the former being regulated by calcium ions and other factors that interact directly with collagen fibrils. ${ }^{46,103,105}$ While stiffening has a similar reaction speed to equivalent phenomena observed in echinoderm MCTs, mesohyl destiffening from the stiff to the standard condition is slower and probably regulated by an enzyme that degrades stiffening factors. As yet, little information is available on reversible destiffening from the standard to the compliant state.

Certain hydrozoan cnidarians have the capacity for autotomy, which may have a role in asexual reproduction and dispersal ${ }^{106,107}$ or defense. ${ }^{108}$ On the basis of morphological and neurophysiological data, it has been proposed that detachment of the tentacles in a hydromedusan may depend on cell-invoked weakening of the collagenous mesogloea at the autotomy plane. $^{108}$ This intriguing possibility needs to be investigated with further studies, including mechanical testing methods.

\section{PRODUCTION OF MARINE COLLAGENS}

3.1. Background. Collagens can be extracted in the native conformation as intact fibrils or in the form of solubilized collagen molecules (tropocollagen). While in the native collagens the triple helix conformation is fully preserved, gelatin, a product derived by the irreversible and partial hydrolysis of collagen molecules, is characterized by the presence of random coil regions. Another class of collagenderived molecules is represented by collagen peptides, which are small fragments obtained from the hydrolysis and enzymatic cleavage of the collagen chains.

3.2. Current Sources: Animals from Natural Stocks. Collagens and collagen-derived molecules (CDMs) from many marine species have been extracted and have been characterized to differing extents. Sponges, cnidarians, molluscs, echinoderms, and especially fish have been the main sources explored.

Species used as natural resources can be classified as being

(a) abundant and sustainable;

(b) not abundant (or widely distributed but not presently exploitable due to their low density) but with the potential to be sustainably farmed in greater numbers;

(c) not abundant and with little potential for exploitation (e.g., due to conservation concerns or because this would be too expensive).

According to which category a species falls into, and according to the general properties of the collagen extracted from it (which also depends on the biology of the species), it is possible to predict potential uses of its collagen. ${ }^{109}$ On the other hand, taxa can be specifically targeted in order to obtain collagen for a specific application. For example, it would not be appropriate to investigate the properties of gelatin obtained from a nonabundant species, while it would be sensible to characterize the properties of native collagen if there were clues that it possessed unique properties that made it suitable for high value-added products. In other words, to meet industrial demands, research must be driven by the likely economic costs associated with extraction and purification of the material and the possible added value of products that must compete in the marketplace. The added value of collagen and CDMs is strictly related to their final applications and varies from 2000 to 4000 $€ /$ ton for fish gelatin used as an additive in the food industry to $2000 € / \mathrm{g}$ for native rat-tail type I collagen (Gibco) used in cell culture. It is also remarkable that, besides the $10^{6}$ difference in price, there are also major differences in traded quantities: the global gelatin market was around 620.6 kilotons in 2019, with fish-derived gelatin accounting for $1 \%$ of this. As the gelatin demand for food and the pharmaceutical industries is increasing, the global market is expected to reach 6.7 billion 
USD by $2027 .^{110}$ This shows that there is a very large market for fish-derived gelatin, which is obtained from abundant but low-value sources, such as fish byproducts, which has enormous growth potential, especially since it can be used by individuals who are allergic to porcine or bovine gelatin and in general it does not conflict with religious restrictions. ${ }^{111,112}$ The target price for marine-derived gelatin has been calculated recently to be less than $100 \mathrm{USD} / \mathrm{kg}$ for the food industry. ${ }^{8}$ Information on the ten most exploited fish species and two most exploited mollusc species, which are all valuable and price-competitive sources of gelatin/CDMs, is provided in Table 3.

\section{Table 3. Most Fished Species in the Seas ${ }^{a}$}

\begin{tabular}{|c|c|c|c|}
\hline Scientific name & Common name & Megatons & Caching trends/notes \\
\hline $\begin{array}{l}\text { Theragra } \\
\text { chalcogramma }\end{array}$ & Alaska pollock & 3.5 & Increasing constantly \\
\hline $\begin{array}{l}\text { Engraulis } \\
\text { ringens }\end{array}$ & $\begin{array}{l}\text { Peruvian } \\
\text { anchovy }\end{array}$ & 3.2 & $\begin{array}{l}\text { Decreasing depending on } \\
\text { southern fluctuation }\end{array}$ \\
\hline $\begin{array}{l}\text { Katsuwonus } \\
\text { pelamis }\end{array}$ & Skipjack tuna & 2.8 & Increasing \\
\hline Sardinella spp. & Sardinella & 2.6 & $\begin{array}{l}\text { Stable/unstable according } \\
\text { to the species }\end{array}$ \\
\hline Trachurus spp. & $\begin{array}{l}\text { Jack and horse } \\
\text { mackerels nei }\end{array}$ & 1.7 & Increasing \\
\hline $\begin{array}{l}\text { Clupea } \\
\text { harengus }\end{array}$ & Atlantic herring & 1.6 & Stable/small fluctuations \\
\hline $\begin{array}{l}\text { Scomber } \\
\text { japonicus }\end{array}$ & $\begin{array}{l}\text { Pacific chub } \\
\text { mackerel }\end{array}$ & 1.6 & Stable \\
\hline $\begin{array}{l}\text { Thunnus } \\
\text { albacares }\end{array}$ & Yellowfin tuna & 1.5 & Stable/small fluctuations \\
\hline Gadus morhua & Atlantic codfish & 1.3 & Stable \\
\hline $\begin{array}{l}\text { Engraulis } \\
\text { japonicus }\end{array}$ & $\begin{array}{l}\text { Japanese } \\
\text { anchovy }\end{array}$ & 1.3 & $\begin{array}{l}\text { Fluctuating but rather } \\
\text { stable }\end{array}$ \\
\hline Dosidicus gigas & $\begin{array}{l}\text { Jumbo flying } \\
\text { squid }\end{array}$ & 0.75 & $\begin{array}{l}\text { Stable with small } \\
\text { fluctuations since } 2004\end{array}$ \\
\hline Illex argentinus & $\begin{array}{l}\text { Argentine } \\
\text { shortfin squid }\end{array}$ & 0.5 & Large fluctuations \\
\hline
\end{tabular}

The market demand for native collagen is quite small in comparison with that for gelatin, but it is generally associated with high value-added products for medical applications where the quality and the properties of the materials must fall within strict parameters. Species that are less abundant or less exploited but possess collagens with specific features can be regarded as a possible source, if the advantages of the materials make them competitive with other already established products or if they can generate innovative products with improved characteristics. ${ }^{113,114}$

3.3. Current Sources: Animals from Aquaculture. The scope for using farmed species for the extraction of native collagen with interesting properties is expanding rapidly, since both the number and the productivity of farmed species have increased in recent years (FAO, 2018). Farming marine organisms might be a promising way to overcome some constraints related to the sustainability and batch variability of collagen sources. Farmed animals are bred in a confined environment in which the ability to control and eventually modify (in the case of inshore facilities) physicochemical parameters could result in more homogeneous and safer collagens. Furthermore, through a selective breeding strategy and sterile hybrid production (see for instance ref 115), it might be possible to select animals that have advantageous characteristics (e.g., high collagen extractability, less pigmentation, less fat) that reduce extraction and purification costs and eliminate the risks of introducing alien species into the environment.

While fish aquaculture has been a long-standing and wellestablished source of collagen, in recent years there have been developments in the farming of other invertebrate taxa. Among those the case of the Japanese sea-cucumber Apostichopus japonicus is particularly interesting, as it might be a sustainable source of mechanically adaptable collagenous biomaterials (FAO, 2018). Pilot offshore farms for sponges that are considered good collagen sources (i.e., Chondrilla nucula and Chondrosia reniformis) have obtained promising results and might in the future overcome the problem of natural stock overexploitation. ${ }^{116}$ Cnidarians, which are another source of unique collagens for tissue engineering, ${ }^{113}$ can also be farmed in a fully controlled environment. ${ }^{114}$

3.4. Collagen Extraction Methods. 3.4.1. Acidic Extraction. Fibrillar collagens, mainly types I, II, III, and V, are generally extracted using acidic treatments after most of the noncollagenous molecules have been washed out or degraded. Both diluted inorganic (hydrochloric) and organic (lactic, citric, chloroacetic, and acetic) acids can be used to solubilize collagen; however, acetic acid is by far the most commonly used. ${ }^{117}$ The mechanism is based on the increasing repulsion forces between tropocollagen chains in acidic conditions that result in solubilization of the less cross-linked collagens; the fraction obtained is composed of acid-soluble collagen (ACS). The density and the type of cross-links between collagen fibrils, which depend on the age of the specimen and the tissue, are thought to influence the extractability of collagens. ${ }^{78}$ Where acidic extraction methods show low efficiency, further enzymatic procedures, mainly based on pepsin treatment, can be used to increase the extraction yield; these methods are used directly on the tissues or after an initial acid treatment and yield pepsin-soluble collagens (PSC). Enzymatic treatments remove the telopeptides that are responsible for more acid-stable links between different tropocollagen chains. These treatments do not affect the nonhelical region and have the added advantage of digesting coextracted contaminant proteins.

Another option that is both innovative and "green" is supercritical fluid extraction (SCF). In SCF water pressurized and acidified with $\mathrm{CO}_{2}$ promotes collagen/gelatin solubilization from the tissues. ${ }^{118}$ Although this is a new method for extracting collagen from marine organisms, promising results have already been reported in the literature, e.g. extraction yields of $50 \%$ collagen/gelatin from marine sponges. ${ }^{118}$ The most attractive aspects of this approach are the relative simplicity of the process; the good yield; the possibility to scale up the process easily; and a significant reduction in costs, given that organic solvents are not required. ${ }^{118}$

3.4.2. Nonacidic Extraction. As described in the previous section, most fibrillar collagens are extracted by using acidic treatments to solubilize the fibrils into their tropocollagen units. There are, however, many cases where extraction in acidic conditions, with or without proteolytic enzymes, is not necessary or results in very low yields (see for instance ref 45). This applies to the mechanically adaptable collagenous tissues of sponges and echinoderms (see section 2.4.2 above), from which intact native collagen fibrils can be extracted using mild buffers. $^{45,103,119,120}$ Matsumura and co-workers ${ }^{120}$ first described the extraction of intact collagen fibrils from 
echinoderms using a solution containing $\mathrm{NaCl}$, Tris- $\mathrm{HCl}$, EDTA, and 2-mercaptoethanol ( $\mathrm{pH} 8)$, and this method has been applied with minor modifications to other echinoderms ${ }^{53,78,93,121}$ and to the sponge C. reniformis. ${ }^{103}$ The mode of action of this solution is not yet clear, but in view of the presence of a divalent ion chelator (EDTA) and disulfide bond reducing agent (2-mercaptoethanol), it can be assumed that the interfibrillar linkage depends at least partly on labile disulfide bonds and other molecules that require the presence of calcium or magnesium ions.

Other techniques for extracting intact collagen fibrils using neutral buffers and mild mechanical force have been applied to the sponge C. reniformis, ${ }^{45,122}$ cnidarians, ${ }^{123}$ and molluscs. ${ }^{38}$

Although the extraction of intact collagen fibrils from adult vertebrates is very difficult, ${ }^{124-126}$ this can be easily achieved in chicken embryos since the collagen is immature and less crosslinked. ${ }^{68}$ This shows that the extractability of collagen, either as single monomers or as intact fibrils, depends largely on the nature of the bonds that hold the collagen fibrils together.

3.5. Recombinant Production. Recombinant techniques offer an alternative method for producing collagens with high biotechnological potential. These techniques can be applied to marine organisms that are rare and/or difficult to breed. The production of collagen in recombinant form offers different advantages: it is more homogeneous, is free of toxic compounds, is easily scalable, and has fewer batch-to-batch variations. Due to collagen post-translational modifications, the yeast eukaryotic model has proved to be a suitable expression system in terms of yield/cost ratio. ${ }^{127}$ With few exceptions, ${ }^{128}$ yeast lacks endogenous prolyl-4-hydroxylase activity and fully hydroxylated human collagen type III has been produced in the methanotrophic yeast Pichia pastoris using a complex tripletransformed strain, which included human type III collagen and the alpha and beta subunits of prolyl-4-hydroxylase genes. $^{129}$ Therefore, besides the collagen coding sequence, this approach requires knowledge of the enzymes involved in post-translational modifications. Recently, the cDNA cloning of a spongin nonfibrillar collagen ${ }^{62}$ and prolyl-4-hydroxylase enzyme $^{130}$ from the marine sponge $C$. reniformis has made it possible to obtain a $P$. pastoris strain that is able to produce hydroxylated marine collagen polypeptides. ${ }^{131}$

However, the recombinant production of stable marinederived triple-helix collagens still faces some limitations, with the major one being the lack of knowledge of the $\alpha$-chain composition. Although there has been significant progress in the sequencing of collagen genes from many marine organisms, ${ }^{54}$ the biochemistry of collagens has not yet been completely elucidated. Obtaining stable triple helices of marine collagens in recombinant form can be a real challenge, since frequently the exact alpha chain composition of the original collagens is not fully known. Often a chain involved in the formation of a collagen heterotrimer can assemble as homotrimers. In addition, long unfolded polypeptides with repeated sequences have an innate tendency to form insoluble aggregates. ${ }^{132}$ The introduction of some form of chemical modification of the $\alpha$-chain, such as the addition of disulfide bonds ${ }^{133}$ or the use of engineered $\alpha$-chains combined with specific sequences that improve the triple helix formation, ${ }^{134}$ could help to overcome these limitations.

The recombinant production of short marine collagen peptides or nontriple helical collagen $\alpha$-chains is less complicated. They do not need any post-translational subunit assembly inside the host cells and can be purified easily in large amounts by chromatographic methods, as described for the $\alpha 1$ (IV) C-terminal domain of the mollusc Haliotis tuberculata. $^{135}$

\section{BIOTECHNOLOGICAL USES OF MARINE COLLAGENS}

4.1. Main Uses of Native Marine Collagens. While there are several reported applications for marine-derived gelatin and collagen peptides (see refs 111 and 136-138), so far there are fewer industrial uses for native collagens, which comprise basically fibrillar types I and II and the nonfibrillar type IV. Native collagen products are still derived mainly from mammalian sources (cattle, pigs, and rats), even though marine collagens cause fewer immunological problems. ${ }^{139,140}$ This disparity between the exploitation of marine and nonmarine collagens is expected to decrease in the future, since the study of marine collagens for biotechnological applications has dramatically increased during the past decade or so. ${ }^{8}$ In fact, initially the studies focused on the extraction and characterization of collagens from different marine organisms, with potential application being barely suggested, but lately several authors have been addressing particular applications for marine collagens, namely in health and well being areas, looking for a particular performance or simply as replacements for collagens from traditional sources. ${ }^{138,141,142}$

Marine collagens from various fish and sponges are already used in the pharmaceutical and cosmeceutical industries due to their good antioxidant and moisturizing properties. ${ }^{143,144}$ Collagen extracted from salmon and codfish skins has proven to be suitable for dermocosmetic applications, which may constitute a platform for the biotechnological valorization of fish byproducts. ${ }^{144}$ C. reniformis collagen is used in cosmeceutical skincare products. ${ }^{145}$ The developed skincare products are intended to protect, or enhance recovery, from damage caused by solar UV radiation, dry skin syndrome, and aging. $^{145-149}$

One emerging field of biotechnology in which marine collagen could play an important role is tissue engineering and regenerative medicine (TERM). ${ }^{141}$ TERM aims to combine materials and cells to improve, restore, or replace tissues and organs. Collagens, which comprise the major component of cellular scaffolding, are biocompatible, are biodegradable, and present different bioactive sites. ${ }^{16,148}$ They are considered to be ideal materials for tissue engineering, having good native mechanical properties and being suitable for different processing techniques such as freeze-drying and $3 \mathrm{D}$ bioprinting. ${ }^{150-152}$

Marine collagens have been used, alone or in combination with other materials, to develop a wide range of biomedical applications such as porous scaffolds, membranes, nanoparticles, and hydrogels, aiming at both soft and hard tissues. $^{142,153-158}$ Cartilage tissue engineering is a challenging field in which marine collagens have been proving to be of valuable biomedical applicability. Porous collagen hydrogels from shark skin have allowed a chondrocyte-like cell line to adhere and proliferate and even support temporary chondrogenic differentiation. ${ }^{153,159}$ Jellyfish collagen can also be used as a tool for cartilage tissue engineering, either as an implant in combination with human stem cells and growth factors or as an enzymatically reticulated injectable hydrogel. ${ }^{160,161}$

Bone tissue engineering (BTE) has also benefited from recent biotechnological developments employing marine collagens from various sources. Scaffolds composed of sea 
Table 4. Crosslinking Strategies Used to Increase the Stability of Native Collagens

\begin{tabular}{|c|c|c|c|c|}
\hline Principle & Methods & Main advantages & Main drawbacks & ref \\
\hline \multirow[t]{3}{*}{ Physical } & DHT & No toxic residues & Can denature collagen & 184 \\
\hline & UV/gamma ray & $\begin{array}{l}\text { No toxic residues, fast, decrease enzymes } \\
\text { sensitivity }\end{array}$ & Only for thin structures & 184 \\
\hline & Macromolecular crowding & Nontoxic & Most suitable for cell culture purpose & 185 \\
\hline \multirow[t]{2}{*}{$\begin{array}{l}\text { Chemical covalent } \\
\text { bond }\end{array}$} & $\begin{array}{l}\text { Aldehydes, carbodiimides, } \\
\text { isocyanates }\end{array}$ & Easy, tunable mechanical properties & Toxic residues & $186-190$ \\
\hline & Genipin & $\begin{array}{l}\text { Fast, simple control of cross-linking degree, } \\
\text { requires low concentrations }\end{array}$ & $\begin{array}{l}\text { Changes in matrix organization, more } \\
\text { expensive, toxic residues }\end{array}$ & 191 \\
\hline $\begin{array}{r}\text { Chemical ionic } \\
\text { complexation }\end{array}$ & Polyanionic chitosan & No toxic residues, easy & Less strong & 192,193 \\
\hline Enzymatic cross-link & Transglutaminase & No toxic residues & More expensive & 194 \\
\hline Combined & Riboflavin/UV A & Used in vivo (ophthalmology) & Depends on light penetration depth & 195 \\
\hline
\end{tabular}

urchin collagen and calcium phosphates are potential candidates for scaffolds for BTE, ${ }^{154}$ with similar composites being reported using fish collagen in combination with hydroxyapatite, studied as templates for culture of bone cells. ${ }^{162,163}$ Besides, biocomposite scaffolds combining jellyfish or fish scales collagen and chitosan have also been produced and studied from a bone regeneration perspective. ${ }^{164,165} \mathrm{~A}$ different concept to tackle this issue employs a biomimetic mineralization approach using shark collagen to fabricate $3 \mathrm{D}$ printable cell-laden hydrogels, which has been designed for engineering hard mineralized tissues. ${ }^{166}$

The fields of skin regeneration and wound healing have also advanced with the investigation on the biomedical potential of marine collagens and collagen peptides. Sea urchin collagenbased scaffolds functionally mimicking the epidermal layer were developed and present an eco-friendly and economically sustainable biomaterial for tissue regenerative medicine. ${ }^{167}$

Tilapia collagen has also been found to have different applications in the TERM field, including the development of hydrogels and biomimetic electrospun collagen nanofibers for wound dressing, which accelerated wound healing, as well as a bioactive ingredient for biomaterials used in alveolar bone regeneration. ${ }^{168-171}$ Collagen peptides from fish and jellyfish were shown to have therapeutic potential by enhancing the wound healing process. ${ }^{172,173}$ In addition, fish collagen is promising in a wide range of biomedical applications, from the development of in vitro $3 \mathrm{D}$ bioprinted drug screening models to drug delivery. ${ }^{174,175}$

Regarding C. reniformis, it is possible to adapt the collagen extraction procedure to alternatively improve the mechanical properties or antioxidant performances of the derived biomaterials, which also proved to be suitable for biotechnological applications. ${ }^{155}$ C. reniformis collagen type IV membranes have been developed for epithelial repair, regeneration, or replacement, ${ }^{176}$ and microparticles derived from collagen of this marine sponge were prepared as dermal delivery systems. ${ }^{156}$ Under the scope of marine sponges' collagens, other species have also been addressed and scaffolds to support bone formation have been developed employing marine sponge collagen alone and in combination with growth factors, as well as incorporating hydroxyapatite ceramic structures. ${ }^{177-179}$

Biotechnological companies employing marine collagen in the TERM field are arising, based on marine sponge, jellyfish, or fish collagen, proposing biomedical applications such as particles for the delivery of compounds and implantable sponges and membranes, which are prototype medical devices for wound healing and regeneration of other soft tissues. $^{156,180,181}$ These few examples demonstrate the versatility and importance of this marine origin protein as biomaterial.

For a more detailed description on marine collagen applications in the biomedical field see refs 126, 138, 141, 142,182 , and 183

The main drawback of using collagen in these applications is the need to stabilize the extracted molecules to confer adequate mechanical and molecular stability on the final constructs. To overcome this problem, several different approaches, based on physical, chemical, or enzymatic processes have been developed and are summarized in Table 4.

4.2. Bioinspired Uses of MCT-Derived Collagen. Echinoderm MCTs are a promising source of native fibrillar collagen and bioinspired smart collagenous materials. A range of echinoderm species have been explored as potential sources of collagen. ${ }^{84,128-130,196-199}$ Among these, the edible sea urchin Paracentrotus lividus has been proposed as a sustainable and low-cost source, since intact collagen fibrils can be easily extracted from byproducts of these animals' food industry. ${ }^{130,200}$ This would counterbalance the relatively low amount of collagen that can be obtained from each animal. Also, the crown-of-thorns starfish Acanthaster planci, whose outbreaks are a major cause of coral reef degradation, has been used for collagen extraction. ${ }^{201}$ The collection and use of these animals as a source of collagen would seem a more ethical way of controlling their abundance than increasingly refining methods for destroying them in situ. ${ }^{202,203}$ Additionally, the size of this species (among the biggest starfish) results in relatively high yields of collagen. In terms of sustainability, sea cucumbers also offer a good opportunity of exploitation, as several species are routinely cultured. ${ }^{204,205}$

Recently, different protocols for the extraction and purification of collagen from MCT structures have been validated with a view to obtaining highly concentrated fibrillar collagen suspensions for the production of marine-inspired biomaterials for TERM applications. ${ }^{130,200}$ As previously underlined, the ultrastructure and biochemistry of most echinoderm collagen fibrils resemble those of mammalian type-I collagen. ${ }^{12,13,76,84,128-130,206-208}$ In contrast to reassembled mammalian-derived collagen fibrils, ${ }^{209}$ echinoderm fibrils extracted in their native conformation display unimpaired ultrastructural and mechanical properties, while preserving their D-period-associated glycosaminoglycan decoration along the fibril length. ${ }^{84,95,130,199,210}$ The maintenance of fibril integrity immediately after extraction and fibril stability in different media is an advantageous feature of these collagens, which facilitates their use in the production of biomaterials for 
Table 5. Overview of Marine Sources of Native Collagens ${ }^{a}$

\begin{tabular}{|c|c|c|c|c|c|}
\hline Species & Extraction method(s) & Collagen type & Source & $\mathrm{DT}\left({ }^{\circ} \mathrm{C}\right)$ & ref \\
\hline \multicolumn{6}{|c|}{ Marine bony fish } \\
\hline Katsuwonus pelamis & ASC/PSC & I & Skull, spines & $16-18$ & 215 \\
\hline Theragra chalcogramma & ASC & $\mathrm{I}$ & Skin & 24.6 & 216 \\
\hline Gadus morhua & PSC & $\mathrm{I}$ & Bones & 14.4 & 217 \\
\hline Thunnus albacares & ASC/PSC & I & Swim bladder & $33 / 34$ & 218 \\
\hline Thunnus alalunga & ASC/PSC & I & Skin & $32.2 / 31.6$ & 219 \\
\hline Pomadasys kaakan & ASC/PSC & $\mathrm{I}$ & Skin & $34 / 33.8$ & 219 \\
\hline Pleurogrammus azonus & PSC & I & Skin & 15 & 220 \\
\hline Lagocephalus gloveri & ASC & I & Skin & 28 & 221 \\
\hline Takifugu rubripes & ASC/PSC & I & Skin & 28.5 & 222 \\
\hline Priacanthus tayenus & PSC & I & Skin & 31.5 & 223 \\
\hline Pogonia cromis & PSC & $\mathrm{I}$ & Bones, scales & $34.5 / 35.3$ & 224 \\
\hline Archosargus probatocephalus & PSC & I & Bones, scales & $34.4 / 33.6$ & 224 \\
\hline Merluccius hubbsi & ASC & I & Skin & 10 & 225 \\
\hline Sebastes mentella & ASC/PSC & I & Skin & $16.1 / 15.7$ & 226 \\
\hline Lutjanus vitta & ASC/PSC & I & Skin & 30.5 & 227 \\
\hline Parupeneus heptacanthus & ASC/PSC & I & Scales & $41.5 / 41$ & 228 \\
\hline Evenchelys macrura & ASC/PSC & I & Skin & $39 / 35$ & 229 \\
\hline Aluterus monocerous & PSC & I & Skin & $29-31$ & 230 \\
\hline Salmo salar & PSC & I & Skin & 18.4 & 231 \\
\hline Oreochromis niloticus & ASC/PSC & I & Skin & $34.5 / 30$ & 232 \\
\hline \multicolumn{6}{|c|}{ Marine cartilaginous fish } \\
\hline Chiloscyllium punctatum & ASC/PSC & $\mathrm{I} / \mathrm{II}$ & Cartilage & $36.2 / 34.7$ & 233 \\
\hline Carcharhinus limbatus & ASC/PSC & $\mathrm{I} / \mathrm{II}$ & Cartilage & $36.7 / 35.9$ & 233 \\
\hline Raja kenojei & PSC & $\mathrm{I} / \mathrm{V} / \mathrm{XI}$ & Skin & 28.8 & 234 \\
\hline Carcharhinus albimarginatus & ASC/PSC & II & Cartilage & $30 / 31.5$ & 235 \\
\hline Scyliorhinus canicula & ASC & I & Skin & n.a. & 153 \\
\hline \multicolumn{6}{|c|}{ Echinoderms } \\
\hline Anthocidaris crassispina & PSC & I & Test (shell) & 28 & 198 \\
\hline Apostichopus japonicus & PSC & $(\alpha 1)_{3}$ & Body wall & n.a. $\left(57^{*}\right)$ & 236 \\
\hline Stichopus vastus & PSC & $(\alpha 1)_{3}$ & Integument & 21.2 & 237 \\
\hline Stichopusmonotuberculatus & PSC & $(\alpha 1)_{3}$ & Body wall & 30.2 & 199 \\
\hline Holothuria parva & PSC & $(\alpha 1)_{3}$ & Skin & 32.5 & 238 \\
\hline Bohadshia spp & PSC & $(\alpha 1)_{3}$ & Body wall & n.a. & 239 \\
\hline Acanthaster planci & PSC & I-like & Body wall & 33 & 201 \\
\hline Asthenosoma ijimai & PSC & $?$ & Test & 23.1 & 240 \\
\hline Asterias amurensis & $\mathrm{DS}+\mathrm{PD}$ & I-like & Body wall & n.a. & 196 \\
\hline Paracentrotus lividus & DS & I & Peristomial membrane & n.a. & 121 \\
\hline Parastichopus californicus & PSC & I-like & Skin/connective tissue & $18.5 / 17.5$ & 241 \\
\hline \multicolumn{6}{|c|}{ Mollusc } \\
\hline Sepia lycidas & ASC/PSC & I & Outer skin & 27 & 242 \\
\hline Argonauta argo & ASC/PSC & I & Outer skin & 27 & 243 \\
\hline Todarodes pacificus & ASC & I & Inner/outer skins & $27.3 / 27.1$ & 244 \\
\hline Callistoctopus arakawai & PSC & $\alpha 1 \alpha 2 \alpha 3$ & Arm & 28 & 245 \\
\hline Illex argentinus & ASC/PSC & I & Skin & $23.2 / 31.5$ & 246 \\
\hline Dosidicus gigas & ASC & n.a. & Mantle & n.a. & 247 \\
\hline Haliotis tuberculata & $\mathrm{MD}$ & IV & Hemocytes & n.a. & 125 \\
\hline Sepia officinalis & ASC/UE & I-like, V & Dermis & n.a. & 38 \\
\hline \multicolumn{6}{|c|}{ Crustaceans } \\
\hline Scylla serrata & PSC & $\mathrm{V}$ & Muscles & $30.2 / 27.8$ & 248 \\
\hline Penaeus indicus & PSC & $\mathrm{V}$ & Muscle & 37 & 249 \\
\hline \multicolumn{6}{|c|}{ Annelids } \\
\hline Alvinella pompejana & ASC & n.a. & Cuticle & 45 & 250 \\
\hline Alvinella caudata & ASC & & Cuticle & 46 & \\
\hline Alvinella grasslei & ASC & & Cuticle & 35 & \\
\hline Arenicola marina & ASC & & Cuticle & 28 & \\
\hline Nereis diversicolor & ASC & & Cuticle & 29 & \\
\hline Alvinella pompejana & PSC & & Body wall & 46 & \\
\hline Alvinella caudata & PSC & & Body wall & 44 & \\
\hline Alvinella grasslei & PSC & & Body wall & 34 & \\
\hline Arenicola marina & PSC & & Body wall & 28 & \\
\hline
\end{tabular}


Table 5. continued

\begin{tabular}{|c|c|c|c|c|c|}
\hline Species & Extraction method(s) & Collagen type & Source & $\mathrm{DT}\left({ }^{\circ} \mathrm{C}\right)$ & ref \\
\hline \multicolumn{6}{|c|}{ Annelids } \\
\hline Nereis diversicolor & PSC & & Body wall & 33 & \\
\hline Riftia pachyptila & ACS & n.a. & Cuticle & 37 & 51 \\
\hline \multicolumn{6}{|c|}{ Cnidarians } \\
\hline Rhopilema asamushi & PSC & II & Mesogloea & 28.8 & 251 \\
\hline Chrysaora quinquecirrha & ASC/PSC & n.a. & Whole, nematocysts & 29 & 252 \\
\hline Cyanea nozakii & ASC/PSC & $(\alpha 1)_{3}$ & Umbrella & 23.8 & 253 \\
\hline Rhizostoma pulmo & ASC/PSC & I & Umbrella, oral arms & 28.9 & 254 \\
\hline Cotylorhiza tuberculata & ASC/PSC & $(\alpha 1)_{3}$ & Umbrella, oral arms & n.a. & \\
\hline Aurelia aurita & ASC/PSC & $(\alpha 1)_{3}$ & Whole & n.a. & \\
\hline Pelagia noctiluca & ASC/PSC & $(\alpha 1)_{3}$ & Whole & n.a. & \\
\hline Catostylus mosaicus & ASC & I & Whole & n.a. & 255 \\
\hline Stomolophus nomurai meleagris & PSC & n.a. & Mesogloea & n.a. & 256 \\
\hline \multicolumn{6}{|c|}{ Sponges } \\
\hline Chondrosia reniformis & DS & n.a & Mesohyl & n.a & 103 \\
\hline Chondrosia reniformis & HM & I & Mesohyl & n.a & 45 \\
\hline Chondrosia reniformis & $\mathrm{BS} / \mathrm{AP}$ & n.a & Meshoyl & n.a & 176 \\
\hline Ircinia fusca & $\mathrm{BS} / \mathrm{AP}$ & I & Whole & n.a & 257 \\
\hline Ircinia fusca & $\mathrm{BS} / \mathrm{AP}$ & IV & Whole & n.a & 257 \\
\hline
\end{tabular}

${ }^{a_{T}}$ The focus was mainly on sources that are considered byproducts of fisheries or species that are of low or no commercial interest. Exceptions were considered when the collagens have particularly interesting or unusual properties. ASC, acid-soluble collagen; BS/AP, basic solubilization/acidic precipitation; DT, denaturation temperature; DS, disaggregating solution; MD, molecular data; PD, pepsin digestion; PSC, pepsin-soluble collagen; $\mathrm{UE}$, urea extraction; *, melting point.

a wide range of applications. Echinoderm collagen has been proposed as a potential alternative to mammalian-derived collagen for both cell culture ${ }^{130}$ and human health applications, such as Guided Tissue Regeneration. ${ }^{200}$ Results obtained so far suggest that echinoderm-derived collagen membranes (EDCMs) could be promising tools for biomedical/clinical purposes, e.g. as barriers to avoid postsurgical tissue adhesion and wound dehiscence, or for tendon/ligament repair and dermis reconstruction. The high mechanical resistance to uniaxial tension (stiffness) and thin membrane thickness (up to $15 \mu \mathrm{m}$ ) of this biomaterial also provide benefits, such as desirable handling properties during surgical procedures, steric hindrance in the wound, and postsurgery resistance. It is notable that these EDCMs have a 20-fold higher mechanical resistance than commercially used bovine collagen membranes. They exhibit no cytotoxicity to mammalian cells, specifically horse-derived mesenchymal stem cells ${ }^{130}$ and human skinderived fibroblasts, ${ }^{200}$ which further confirms their potential usefulness for biomedical applications.

The adaptable mechanical properties of MCTs have stimulated ideas for synthetic "smart biomaterials", ${ }^{211}$ which require the development of reagents that can mimic cross-links between collagen fibrils in order to obtain chemically controlled composite biomaterials with dynamically controlled stiffness. A mechanically adaptable sea cucumber dermis has also inspired the development of stimulus-responsive polymer nanocomposites that could be used as substrates for implantable microelectrodes. ${ }^{212}$ The peptides that regulate MCT mechanical properties in vivo (see section 2.4.2) are another target of investigation for potential therapeutic or cosmetic benefits, although there is no evidence that they have any effects on nonechinoderm tissues yet.

4.3. Uses of Intact Collagen Fibrils. Due to their interesting mechanical properties (discussed in section 3.4.2), collagen fibrils derived from the marine sponge $C$. reniformis were isolated using four different extraction methods and their ability to form thin membranes was tested. It was demonstrated that treatment of sponge tissue with a low concentration of trypsin followed by extensive water extraction was the most adequate method to obtain intact collagen fibrils suitable for producing antioxidant, biocompatible, and resistant membranes for TERM applications, achievable even without the need of any cross-linking reaction. ${ }^{155}$ Using the same extraction method, an extract of $C$. reniformis intact fibrils was used to produce collagen hydrolysates which proved to have antioxidant, wound-healing, and photoprotective properties. ${ }^{149}$

Furthermore, intact collagen fibers derived from the soft coral Sarcophyton, obtained by mechanical extraction without the use of any acid or enzyme, have proven to be a suitable material for biomedical applications due to their biocompatibility and good mechanical properties. ${ }^{213}$ These unique collagen fibers can be used as scaffolds for tissue regeneration in support of the healing process, enabling the cell migration and new blood vessel formation needed for tissue repair. ${ }^{214}$

\section{CONCLUDING REMARKS}

Collagen is an abundant natural polymer that has been used in both its native and denatured forms in a wide range of applications. Marine collagens from a range of phyla have been successfully extracted and characterized. However, teleost fish and their industrial byproducts represent the most exploited sources, and it is only recently that other taxa have been investigated intensively as potential sources of collagens with special features. Marine invertebrates are highly diverse, and although many of their collagens have been found to have interesting properties, few have been investigated in detail. A particular example is the case of collagens from animals with unusual connective tissue physiology, particularly those of echinoderms. These collagens have been identified and studied from the biochemical point-of-view, aiming to understand the mechanism governing the dynamic behavior observed, but their full potential has not been further explored. Elucidating the mechanisms underpinning the mechanical adaptability of 
echinoderm MCTs and other mechanically adaptable collagenous tissues could shed light on different pathologies affecting human connective tissue and could lead to biomedical advances, such as collagenous constructs with controllable properties. In this regard, while the study of fish collagen can open the door for its use as an alternative to mammalian collagen, invertebrate collagen can enable a step further, with its unique characteristics supporting the development of smart biomaterials and exploring new functionalities.

The identification of biotechnological applications for the diverse and largely unexplored abundance of invertebrate collagens will require the cooperation of experts in marine biology, biotechnology, and the clinical sciences. The oceans are immense and realizing their potential for benefiting human well-being demands a correspondingly ambitious program of collaborative research. To emphasize these points, an overview of marine sources of native collagens is provided below (Table $5)$.

\section{AUTHOR INFORMATION}

\section{Corresponding Author}

Tiago H. Silva - 3B's Research Group, I3Bs - Research Institute on Biomaterials, Biodegradables and Biomimetics, University of Minho, Headquarters of the European Institute of Excellence on Tissue Engineering and Regenerative Medicine, AvePark, Parque de Ciencia e Tecnologia, Zona Industrial da Gandra, 4805-017 Barco, Guimarães, Portugal; ICVS/3B's-PT Government Associate Laboratory, Braga, Guimarães, Portugal; @ orcid.org/0000-0001-8520603X; Email: tiago.silva@i3bs.uminho.pt

\section{Authors}

Dario Fassini - 3B's Research Group, I3Bs - Research Institute on Biomaterials, Biodegradables and Biomimetics, University of Minho, Headquarters of the European Institute of Excellence on Tissue Engineering and Regenerative Medicine, AvePark, Parque de Cîencia e Tecnologia, Zona Industrial da Gandra, 4805-017 Barco, Guimarães, Portugal; ICVS/3B's-PT Government Associate Laboratory, Braga, Guimarães, Portugal

Iain C. Wilkie - Institute of Biodiversity Animal Health \& Comparative Medicine, University of Glasgow, Glasgow G12 $8 Q Q$ Scotland

Marina Pozzolini - Department of Earth, Environment and Life Sciences (DISTAV), University of Genova, 16132 Genova, Italy

Cinzia Ferrario - Dipartimento di Scienze e Politiche Ambientali, Università degli Studi di Milano, Milano, Italy, Center for Complexity \& Biosystems, Dipartimento di Fisica, Università degli Studi di Milano, 20122 Milano, Italy

Michela Sugni - Dipartimento di Scienze e Politiche Ambientali, Università degli Studi di Milano, Milano, Italy, Center for Complexity \& Biosystems, Dipartimento di Fisica, Università degli Studi di Milano, 20122 Milano, Italy

Miguel S. Rocha - 3B's Research Group, I3Bs - Research Institute on Biomaterials, Biodegradables and Biomimetics, University of Minho, Headquarters of the European Institute of Excellence on Tissue Engineering and Regenerative Medicine, AvePark, Parque de Cîencia e Tecnologia, Zona Industrial da Gandra, 4805-017 Barco, Guimarães, Portugal; ICVS/3B's-PT Government Associate Laboratory, Braga, Guimarães, Portugal
Marco Giovine - Department of Earth, Environment and Life Sciences (DISTAV), University of Genova, 16132 Genova, Italy

Francesco Bonasoro - Dipartimento di Scienze e Politiche Ambientali, Università degli Studi di Milano, Milano, Italy, Center for Complexity \& Biosystems, Dipartimento di Fisica, Università degli Studi di Milano, 20122 Milano, Italy

Rui L. Reis - 3B's Research Group, I3Bs - Research Institute on Biomaterials, Biodegradables and Biomimetics, University of Minho, Headquarters of the European Institute of Excellence on Tissue Engineering and Regenerative Medicine, AvePark, Parque de Ciencia e Tecnologia, Zona Industrial da Gandra, 4805-017 Barco, Guimarães, Portugal; ICVS/ 3B's-PT Government Associate Laboratory, Braga, Guimarães, Portugal

Complete contact information is available at: https://pubs.acs.org/10.1021/acs.biomac.1c00013

\section{Notes}

The authors declare no competing financial interest.

\section{ACKNOWLEDGMENTS}

The authors are grateful for the financial support from European Union, under the scope of European Regional Development Fund((ERDF) through the POCTEP project 0687_NOVOMAR_1_P and Structured Project NORTE-010145-FEDER-000021 and from the Portuguese Foundation for Science and Technology (FCT), under the scope of the BiogenInk project (M-ERA-NET2/0022/2016) and from the European Cooperation in Science \& Technology program (EU COST). Grant title: "Stem cells of marine/aquatic invertebrates: from basic research to innovative applications" (MARISTEM). MSR acknowledges FCT for the Ph.D. scholarship (PD/BD/143091/2018).

\section{REFERENCES}

(1) Mora, C.; Tittensor, D. P.; Adl, S.; Simpson, A. G. B.; Worm, B. How Many Species Are There on Earth and in the Ocean? PLoS Biol. 2011, 9 (8), e1001127.

(2) Appeltans, W.; Ahyong, S. T.; Anderson, G.; Angel, M. V.; Artois, T.; Bailly, N.; Bamber, R.; Barber, A.; Bartsch, I.; Berta, A.; Błazewicz-Paszkowycz, M.; Bock, P.; Boxshall, G.; Boyko, C. B.; Brandão, S. N.; Bray, R. A.; Bruce, N. L.; Cairns, S. D.; Chan, T. Y.; Cheng, L.; Collins, A. G.; Cribb, T.; Curini-Galletti, M.; DahdouhGuebas, F.; Davie, P. J. F.; Dawson, M. N.; De Clerck, O.; Decock, W.; De Grave, S.; De Voogd, N. J.; Domning, D. P.; Emig, C. C.; Erséus, C.; Eschmeyer, W.; Fauchald, K.; Fautin, D. G.; Feist, S. W.; Fransen, C. H. J. M.; Furuya, H.; Garcia-Alvarez, O.; Gerken, S.; Gibson, D.; Gittenberger, A.; Gofas, S.; Gómez-Daglio, L.; Gordon, D. P.; Guiry, M. D.; Hernandez, F.; Hoeksema, B. W.; Hopcroft, R. R.; Jaume, D.; Kirk, P.; Koedam, N.; Koenemann, S.; Kolb, J. B.; Kristensen, R. M.; Kroh, A.; Lambert, G.; Lazarus, D. B.; Lemaitre, R.; Longshaw, M.; Lowry, J.; MacPherson, E.; Madin, L. P.; Mah, C.; Mapstone, G.; McLaughlin, P. A.; Mees, J.; Meland, K.; Messing, C. G.; Mills, C. E.; Molodtsova, T. N.; Mooi, R.; Neuhaus, B.; Ng, P. K. L.; Nielsen, C.; Norenburg, J.; Opresko, D. M.; Osawa, M.; Paulay, G.; Perrin, W.; Pilger, J. F.; Poore, G. C. B.; Pugh, P.; Read, G. B.; Reimer, J. D.; Rius, M.; Rocha, R. M.; Saiz-Salinas, J. I.; Scarabino, V.; Schierwater, B.; Schmidt-Rhaesa, A.; Schnabel, K. E.; Schotte, M.; Schuchert, P.; Schwabe, E.; Segers, H.; Self-Sullivan, C.; Shenkar, N.; Siegel, V.; Sterrer, W.; Stöhr, S.; Swalla, B.; Tasker, M. L.; Thuesen, E. V.; Timm, T.; Todaro, M. A.; Turon, X.; Tyler, S.; Uetz, P.; Van Der Land, J.; Vanhoorne, B.; Van Ofwegen, L. P.; Van Soest, R. W. M.; Vanaverbeke, J.; Walker-Smith, G.; Walter, T. C.; Warren, A.; Williams, G. C.; Wilson, S. P.; Costello, M. J. The Magnitude of 
Global Marine Species Diversity. Curr. Biol. 2012, 22 (23), 21892202 and others.

(3) Scheuer, P. J. Some Marine Ecological Phenomena: Chemical Basis and Biomedical Potential. Science (Washington, DC, U. S.) 1990, 248 (4952), 173-177.

(4) Schumacher, M.; Kelkel, M.; Dicato, M.; Diederich, M. Gold from the Sea: Marine Compounds as Inhibitors of the Hallmarks of Cancer. Biotechnol. Adv. 2011, 29 (5), 531-547.

(5) Leal, M. C.; Madeira, C.; Brandão, C. A.; Puga, J.; Calado, R. Bioprospecting of Marine Invertebrates for New Natural Products - A Chemical and Zoogeographical Perspective. Molecules 2012, 17 (8), 9842-9854.

(6) Garrone, R. Collagen, a Common Thread in Extracellular Matrix Evolution. Proc. Indian Acad. Sci. Chem. Sci. 1999, 111 (1), 51-56.

(7) Özbek, S.; Balasubramanian, P. G.; Chiquet-Ehrismann, R.; Tucker, R. P.; Adams, J. C. The Evolution of Extracellular Matrix. Mol. Biol. Cell 2010, 21 (24), 4300-4305.

(8) Silva, T. H.; Moreira-Silva, J.; Marques, A. L. P.; Domingues, A.; Bayon, Y.; Reis, R. L. Marine Origin Collagens and Its Potential Applications. Mar. Drugs 2014, 12 (12), 5881-5901.

(9) Syed, T.; Schierwater, B. The Evolution of the Placozoa: A New Morphological Model. Senckenbergiana Lethaea 2002, 82 (1), 315324.

(10) Clément, P. The Phylogeny of Rotifers: Molecular, Ultrastructural and Behavioural Data. Hydrobiologia 1993, 255-256 (1), 527-544.

(11) Exposito, J.-Y. Y.; Valcourt, U.; Cluzel, C.; Lethias, C. The Fibrillar Collagen Family. Int. J. Mol. Sci. 2010, 11 (2), 407-426.

(12) Wilkie, I. Subseries Marine Molecular Biotechnology, Echinodermata. In Progress in Molecular and Subcellular Biology, 39; Springer-Verlag: Berlin Heidelberg, 2005; pp 221-250.

(13) Gelse, K.; Pöschl, E.; Aigner, T. Collagens - Structure, Function, and Biosynthesis. Adv. Drug Delivery Rev. 2003, 55 (12), $1531-1546$

(14) Schuppan, D.; Schmid, M.; Somasundaram, R.; Ackermann, R.; Ruehl, M.; Nakamura, T.; Riecken, E. O. Collagens in the Liver Extracellular Matrix Bind Hepatocyte Growth Factor. Gastroenterology 1998, 114 (1), 139-152.

(15) Czirók, A.; Rongish, B. J.; Little, C. D. Extracellular Matrix Dynamics during Vertebrate Axis Formation. Dev. Biol. 2004, 268 (1), $111-122$.

(16) Di Lullo, G. A.; Sweeney, S. M.; Körkkö, J.; Ala-Kokko, L.; San Antonio, J. D. Mapping the Ligand-Binding Sites and DiseaseAssociated Mutations on the Most Abundant Protein in the Human, Type I Collagen. J. Biol. Chem. 2002, 277 (6), 4223-4231.

(17) Pankov, R.; Yamada, K. Fibronectin at a Glance. J. Cell Sci. 2002, 115 (20), 3861-3863.

(18) Bou-Gharios, G.; De Crombrugghe, B. Type I Collagen Structure, Synthesis, and Regulation. In Principles of Bone Biology, Two-Vol. Set; Bilezkian, L. G. R., Rodan, G. A., Eds.; Principles in Bone Biology; Academic Press: Orlando, 2008; Vol. 1, pp 189-210, 285-318. DOI: 10.1016/B978-0-12-373884-4.00034-3.

(19) Steinmann, B.; Bruckner, P.; Superti-Furga, A. Cyclosporin A Slows Collagen Triple-Helix Formation in Vivo: Indirect Evidence for a Physiologic Role of Peptidyl-Prolyl Cis-Trans-Isomerase. J. Biol. Chem. 1991, 266 (2), 1299-1303.

(20) Bateman, J. F.; Lamande, S. R.; Ramshaw, J. A. M. Collagen Superfamily. In Extracellular Matrix; Comper, W. D., Ed.; Harwood Academic Publishers: Amsterdam, 1996; pp 22-67.

(21) Prockop, D. J.; Sieron, A. L.; Li, S. W. Procollagen N-Proteinase and Procollagen C-Proteinase. Two Unusual Metalloproteinases That Are Essential for Procollagen Processing Probably Have Important: Roles in Development and Cell Signaling. Matrix Biol. 1998, 16 (7), 399-408.

(22) Bailey, A.; Paul, R.; Knott, L. Mechanisms of Maturation and Ageing of Collagen. Mech. Ageing Dev. 1998, 106 (1-2), 1-56.

(23) Reddy, G. K.; Hudson, B. G.; Bailey, A. J.; Noelken, M. E. Reductive Cleavage of the Disulfide Bonds of the Collagen IV Noncollagenous Domain in Aqueous Sodium Dodecyl Sulfate:
Absence of Intermolecular Nondisulfide Cross-Links. Biochem. Biophys. Res. Commun. 1993, 190 (1), 277-282.

(24) Shoulders, M. D.; Raines, R. T. Collagen Structure and Stability. Annu. Rev. Biochem. 2009, 78 (1), 929-958.

(25) Wenstrup, R. J.; Smith, S. M.; Florer, J. B.; Zhang, G.; Beason, D. P.; Seegmiller, R. E.; Soslowsky, L. J.; Birk, D. E. Regulation of Collagen Fibril Nucleation and Initial Fibril Assembly Involves Coordinate Interactions with Collagens $\mathrm{V}$ and $\mathrm{XI}$ in Developing Tendon. J. Biol. Chem. 2011, 286 (23), 20455-20465 and others.

(26) Prockop, D. J. Collagens: Molecular Biology, Diseases, and Potentials for Therapy. Annu. Rev. Biochem. 1995, 64 (1), 403-434.

(27) Pihlajaniemi, T.; Tryggvason, K.; Myers, J. C.; Kurkinen, M.; Lebo, R.; Cheung, M. C.; Prockop, D. J.; Boyd, C. D. CDNA Clones Coding for the Pro-A1(IV) Chain of Human Type IV Procollagen Reveal an Unusual Homology of Amino Acid Sequences in Two Halves of the Carboxyl-Terminal Domain. J. Biol. Chem. 1985, 260 (12), 7681-7687.

(28) Kapoor, R.; Sakai, L. Y.; Funk, S.; Roux, E.; Bornstein, P.; Sage, E. H. Type VIII Collagen Has a Restricted Distribution in Specialized Extracellular Matrices. J. Cell Biol. 1988, 107 (2), 721-730.

(29) Gannon, J.; Walker, G.; Fischer, M.; Carpenter, R.; Thompson, R.; Oegema, T. Localization of Type X Collagen in Canine Growth Plate and Adult Canine Articular Cartilage. J. Orthop. Res. 1991, 9 (4), 485-494.

(30) Keene, D. R.; Sakai, L. Y.; Lunstrum, G. P.; Morris, N. P.; Burgeson, R. E.; Re, B. Type VII Collagen Forms an Extended Network of Anchoring Fibrils. J. Cell Biol. 1987, 104 (3), 611-621.

(31) Bonaldo, P.; Russo, V.; Bucciotti, F.; Doliana, R.; Colombatti, A. Structural and Functional Features of the A3 Chain Indicate a Bridging Role for Chicken Collagen VI in Connective Tissues. Biochemistry 1990, 29 (5), 1245-1254.

(32) Bruns, R. R.; Press, W.; Engvall, E.; Timpl, R.; Gross, J. Type VI Collagen in Extracellular, 100-Nm Periodic Filaments and Fibrils: Identification by Immunoelectron Microscopy. J. Cell Biol. 1986, 103 (2), 393-404.

(33) Sugrue, S. Immunoidentification of Type XII Collagen in Embryonic Tissues. J. Cell Biol. 1989, 109 (2), 939-945.

(34) Van Der Rest, M.; Dublet, B. Type XII and Type XIV Collagens: Interfibrillar Constituents of Dense Connective Tissues. Semin. Cell Dev. Biol. 1996, 7 (5), 639-648.

(35) Vaughan, L.; Mendler, M.; Huber, S.; Bruckner, P.; Winterhalter, K. H.; Irwin, M. I.; Mayne, R. D-Periodic Distribution of Collagen Type IX along Cartilage Fibrils. J. Cell Biol. 1988, 106 (3), 991-997.

(36) Watt, S. L.; Lunstrum, G. P.; McDonough, A. M.; Keene, D. R.; Burgeson, R. E.; Morris, N. P. Characterization of Collagen Types XII and XIV from Fetal Bovine Cartilage. J. Biol. Chem. 1992, 267 (28), 20093-20099.

(37) Rigo, C.; Hartmann, D. J.; Bairati, A. Electrophoretic and Immunochemical Study of Collagens from Sepia Officinalis Cartilage. Biochim. Biophys. Acta, Gen. Subj. 2002, 1572 (1), 77-84.

(38) Bairati, A.; Gioria, M. Collagen Fibrils of an Invertebrate (Sepia Officinalis) Are Heterotypic: Immunocytochemical Demonstration. J. Struct. Biol. 2004, 147 (2), 159-165.

(39) Aouacheria, A.; Geourjon, C.; Aghajari, N.; Navratil, V.; Deleage, G.; Lethias, C. Insights into Early Extracellular Matrix Evolution: Spongin Short Chain Collagen-Related Proteins Are Homologous to Basement Membrane Type IV Collagens and Form a Novel Family Widely Distributed in Invertebrates. Mol. Biol. Evol. 2006, 23 (12), 2288-2302 and others.

(40) Thurmond, F. A.; Trotter, J. A. Morphology and Biomechanics of the Microfibrillar Network of Sea Cucumber Dermis. J. Exp. Biol. 1996, 199 (8), 1817-1828.

(41) Wilkie, I. C.; McKew, M.; Candia Carnevali, M. D. Functional Morphology of the Compass-Rotular Ligament of Echinus Esculentus (Echinodermata: Echinoida): A Non-Mutable Collagenous Component of Aristotle's Lantern. Zoomorphology 2005, 124 (1), 9-26.

(42) Kimura, S.; Ohno, Y. Fish Type I Collagen: Tissue-Specific Existence of Two Molecular Forms, (A1) $2 \alpha 2$ and A1 $\alpha 2 \alpha 3$, in Alaska 
Pollack. Comp. Biochem. Physiol. - Part B Biochem. 1987, 88 (2), 409413.

(43) Saito, M.; Takenouchi, Y.; Kunisaki, N.; Kimura, S. Complete Primary Structure of Rainbow Trout Type I Collagen Consisting of A1(I)A2(I)A3(I) Heterotrimers. Eur. J. Biochem. 2001, 268 (10), 2817-2827.

(44) Koch, M.; Laub, F.; Zhou, P.; Hahn, R. A.; Tanaka, S.; Burgeson, R. E.; Gerecke, D. R.; Ramirez, F.; Gordon, M. K. Collagen XXIV, a Vertebrate Fibrillar Collagen with Structural Features of Invertebrate Collagens: Selective Expression in Developing Cornea and Bone. J. Biol. Chem. 2003, 278 (44), 43236-43244 and others.

(45) Heinemann, S.; Ehrlich, H.; Douglas, T.; Heinemann, C.; Worch, H.; Schatton, W.; Hanke, T. Ultrastructural Studies on the Collagen of the Marine Sponge Chondrosia Reniformis Nardo. Biomacromolecules 2007, 8 (11), 3452-3457 and others.

(46) Wilkie, I. C.; Parma, L.; Bonasoro, F.; Bavestrello, G.; Cerrano, C.; Candia Carnevali, M. D. Mechanical Adaptability of a Sponge Extracellular Matrix: Evidence for Cellular Control of Mesohyl Stiffness in Chondrosia Reniformis Nardo. J. Exp. Biol. 2006, 209 (22), 4436-4443.

(47) Ehrlich, H.; Deutzmann, R.; Brunner, E.; Cappellini, E.; Koon, H.; Solazzo, C.; Yang, Y.; Ashford, D.; Thomas-Oates, J.; Lubeck, M.; Baessmann, C.; Langrock, T.; Hoffmann, R.; Wörheide, G.; Reitner, J.; Simon, P.; Tsurkan, M.; Ereskovsky, A. V.; Kurek, D.; Bazhenov, V. V.; Hunoldt, S.; Mertig, M.; Vyalikh, D. V.; Molodtsov, S. L.; Kummer, K.; Worch, H.; Smetacek, V.; Collins, M. J. Mineralization of the Metre-Long Biosilica Structures of Glass Sponges Is Templated on Hydroxylated Collagen. Nat. Chem. 2010, 2 (12), 1084-1088 and others.

(48) Benayahu, Y.; Benayahu, D.; Kashman, Y.; Rudi, A.; Lanir, Y.; Sella, I.; Raz, E.; Benayahu Yehuda IL, H.; Benayahu Dafna IL, H.; Kashman Yoel IL, T.-A.; Rudi Amira IL, R.-H.; Lanir Yoram IL, H.; Sella Ido IL, M. Z.; Raz Einat IL, M. A. Method of Regenerating Connective Tissue with a Scaffold of Coral-Derived Collagen. 2014, No. US8747484 B2.

(49) Özbek, S.; Pertz, O.; Schwager, M.; Lustig, A.; Holstein, T.; Engel, J. Structure/Function Relationships in the Minicollagen of Hydra Nematocysts. J. Biol. Chem. 2002, 277 (51), 49200-49204.

(50) Gaill, F.; Mann, K.; Wiedemann, H.; Engel, J.; Timpl, R. Structural Comparison of Cuticle and Interstitial Collagens from Annelids Living in Shallow Sea-Water and at Deep-Sea Hydrothermal Vents. J. Mol. Biol. 1995, 246 (2), 284-294.

(51) Mann, K.; Mechling, D. E.; Bächinger, H. P.; Eckerskorn, C.; Gaill, F.; Timpl, R. Glycosylated Threonine but Not 4-Hydroxyproline Dominates the Triple Helix Stabilizing Positions in the Sequence of a Hydrothermal Vent Worm Cuticle Collagen. J. Mol. Biol. 1996, 261 (2), 255-266.

(52) Qin, X. X.; Coyne, K. J.; Waite, J. H. Tough Tendons. Mussel Byssus Has Collagen with Silk-like Domains. J. Biol. Chem. 1997, 272 (51), 32623-32627.

(53) Trotter, J. A.; Thurmond, F. A.; Koob, T. J. Molecular Structure and Functional Morphology of Echinoderm Collagen Fibrils. Cell Tissue Res. 1994, 275 (3), 451-458.

(54) Srivastava, M.; Simakov, O.; Chapman, J.; Fahey, B.; Gauthier, M.; Mitros, T. The Amphimedon Queenslandica Genome and the Evolution of Animal Complexity. Nature 2010, 466 (7307), 720-726.

(55) Exposito, J. Y.; Larroux, C.; Cluzel, C.; Valcourt, U.; Lethias, C.; Degnan, B. M. Demosponge and Sea Anemone Fibrillar Collagen Diversity Reveals the Early Emergence of A/C Clades and the Maintenance of the Modular Structure of Type V/XI Collagens from Sponge to Human. J. Biol. Chem. 2008, 283 (42), 28226-28235.

(56) Exposito, J. Y.; D’Alessio, M.; Ramirez, F. Novel AminoTerminal Propeptide Configuration in a Fibrillar Procollagen Undergoing Alternative Splicing. J. Biol. Chem. 1992, 267 (24), 17404-17408.

(57) Exposito, J. Y.; Garrone, R. Characterization of a Fibrillar Collagen Gene in Sponges Reveals the Early Evolutionary Appearance of Two Collagen Gene Families. Proc. Natl. Acad. Sci. U. S. A. 1990, 87 (17), 6669-6673.
(58) Linsenmayer, T. F.; Gibney, E.; Igoe, F.; Gordon, M. K.; Fitch, J. M.; Fessler, L. I.; Birk, D. E. Type V Collagen: Molecular Structure and Fibrillar Organization of the Chicken $\mathrm{A} 1(\mathrm{~V})$ NH2-Terminal Domain, a Putative Regulator of Corneal Fibrillogenesis. J. Cell Biol. 1993, 121 (5), 1181-1189.

(59) Pöschl, E.; Pollner, R.; Kühn, K. The Genes for the Alpha 1(IV) and Alpha 2(IV) Chains of Human Basement Membrane Collagen Type IV Are Arranged Head-to-Head and Separated by a Bidirectional Promoter of Unique Structure. EMBO J. 1988, 7 (9), 26872695.

(60) Fidler, A. L.; Darris, C. E.; Chetyrkin, S. V.; Pedchenko, V. K.; Boudko, S. P.; Brown, K. L.; Gray Jerome, W.; Hudson, J. K.; Rokas, A.; Hudson, B. G. Collagen IV and Basement Membrane at the Evolutionary Dawn of Metazoan Tissues. eLife 2017, 6 (24176). DOI: $10.7554 /$ eLife.24176.

(61) Exposito, J. Y.; Ouazana, R.; Garrone, R. Cloning and Sequencing of a Porifera Partial CDNA Coding for a Short-Chain Collagen. Eur. J. Biochem. 1990, 190 (2), 401-406.

(62) Pozzolini, M.; Bruzzone, F.; Berilli, V.; Mussino, F.; Cerrano, C.; Benatti, U.; Giovine, M. Molecular Characterization of a Nonfibrillar Collagen from the Marine Sponge Chondrosia Reniformis Nardo 1847 and Positive Effects of Soluble Silicates on Its Expression. Mar. Biotechnol. 2012, 14 (3), 281-293 and others.

(63) Johnstone, I. L. Cuticle Collagen Genes: Expression in Caenorhabditis Elegans. Trends Genet. 2000, 16 (1), 21-27.

(64) Ehrlich, H.; Wysokowski, M.; Zółtowska-Aksamitowska, S.; Petrenko, I.; Jesionowski, T. Collagens of Poriferan Origin. Mar. Drugs 2018, 16 (3), 79.

(65) Jesionowski, T.; Norman, M.; Zóltowska-Aksamitowska, S.; Petrenko, I.; Joseph, Y.; Ehrlich, H. Marine Spongin: Naturally Prefabricated 3D Scaffold-Based Biomaterial. Mar. Drugs 2018, 16 (3), 88 .

(66) Buchanan, C. I.; Marsh, R. L. Effects of Exercise on the Biomechanical, Biochemical and Structural Properties of Tendons. Comp. Biochem. Physiol., Part A: Mol. Integr. Physiol. 2002, 133 (4), 1101-1107.

(67) Silver, F. H.; Freeman, J. W.; Seehra, G. P. Collagen SelfAssembly and the Development of Tendon Mechanical Properties. J. Biomech. 2003, 36 (10), 1529-1553.

(68) McBride, D. J.; Trelstad, R. L.; Silver, F. H. Structural and Mechanical Assessment of Developing Chick Tendon. Int. J. Biol. Macromol. 1988, 10 (4), 194-200.

(69) Westergren-Thorsson, G.; Norman, M.; Björnsson, S.; Endrésen, U.; Stjernholm, Y.; Ekman, G.; Malmström, A. Differential Expressions of MRNA for Proteoglycans, Collagens and Transforming Growth Factor- $\beta$ in the Human Cervix during Pregnancy and Involution. Biochim. Biophys. Acta, Mol. Basis Dis. 1998, 1406 (2), 203-213.

(70) Yoshida, M. Prostaglandin F2alpha, Cytokines and Cyclic Mechanical Stretch Augment Matrix Metalloproteinase-1 Secretion from Cultured Human Uterine Cervical Fibroblast Cells. Mol. Hum. Reprod. 2002, 8 (7), 681-687.

(71) Sennström, M. B.; Brauner, A.; Byström, B.; Malmström, A.; Ekman, G. Matrix Metalloproteinase-8 Correlates with the Cervical Ripening Process in Humans. Acta Obstet. Gynecol. Scand. 2003, 82 (10), 904-911.

(72) Timmons, B.; Akins, M.; Mahendroo, M. Cervical Remodeling during Pregnancy and Parturition. Trends Endocrinol. Metab. 2010, 21 (6), 353-361.

(73) Tamori, M.; Yamada, A.; Nishida, N.; Motobayashi, Y.; Oiwa, K.; Motokawa, T. Tensilin-like Stiffening Protein from Holothuria Leucospilota Does Not Induce the Stiffest State of Catch Connective Tissue. J. Exp. Biol. 2006, 209 (9), 1594-1602.

(74) Yamada, A.; Tamori, M.; Iketani, T.; Oiwa, K.; Motokawa, T. A. A Novel Stiffening Factor Inducing the Stiffest State of Holothurian Catch Connective Tissue. J. Exp. Biol. 2010, 213 (20), $3416-3422$

(75) Barbaglio, A.; Tricarico, S.; Ribeiro, A.; Ribeiro, C.; Sugni, M.; Di Benedetto, C.; Wilkie, I.; Barbosa, M.; Bonasoro, F.; Candia 
Carnevali, M. D. The Mechanically Adaptive Connective Tissue of Echinoderms: Its Potential for Bio-Innovation in Applied Technology and Ecology. Mar. Environ. Res. 2012, 76 (C), 108-113.

(76) Ribeiro, A. R.; Barbaglio, A.; Oliveira, M. J.; Ribeiro, C. C.; Wilkie, I. C.; Candia Carnevali, M. D.; Barbosa, M. A. Matrix Metalloproteinases in a Sea Urchin Ligament with Adaptable Mechanical Properties. PLoS One 2012, 7 (11), No. e49016.

(77) Barbaglio, A.; Tricarico, S.; Ribeiro, A. R.; Di Benedetto, C.; Barbato, M.; Dessì, D.; Fugnanesi, V.; Magni, S.; Mosca, F.; Sugni, M.; Bonasoro, F.; Barbosa, M. A.; Wilkie, I. C.; Candia Carnevali, M. D. Ultrastructural and Biochemical Characterization of Mechanically Adaptable Collagenous Structures in the Edible Sea Urchin Paracentrotus Lividus. Zoology 2015, 118 (3), 147-160.

(78) Wilkie, I. C.; Fassini, D.; Cullorà, E.; Barbaglio, A.; Tricarico, S.; Sugni, M.; Del Giacco, L.; Candia Carnevali, M. D. Mechanical Properties of the Compass Depressors of the Sea-Urchin Paracentrotus Lividus (Echinodermata, Echinoidea) and the Effects of Enzymes, Neurotransmitters and Synthetic Tensilin-like Protein. PLoS One 2015, 10 (3), No. e0120339.

(79) Mo, J.; Prévost, S. F.; Blowes, L. M.; Egertová, M.; Terrill, N. J.; Wang, W.; Elphick, M. R.; Gupta, H. S. Interfibrillar Stiffening of Echinoderm Mutable Collagenous Tissue Demonstrated at the Nanoscale. Proc. Natl. Acad. Sci. U. S. A. 2016, 113 (42), E6362E6371.

(80) Ribeiro, A. R.; Barbaglio, A.; Benedetto, C. D.; Ribeiro, C. C.; Wilkie, I. C.; Candia Carnevali, M. D.; Barbosa, M. A. New Insights into Mutable Collagenous Tissue: Correlations between the Microstructure and Mechanical State of a Sea-Urchin Ligament. PLoS One 2011, 6 (9), No. e24822-10.

(81) Ribeiro, A. R.; Barbaglio, A.; Oliveira, M. J.; Santos, R.; Coelho, A. V.; Ribeiro, C. C.; Wilkie, I. C.; Candia Carnevali, M. D.; Barbosa, M. A. Correlations between the Biochemistry and Mechanical States of a Sea-Urchin Ligament: A Mutable Collagenous Structure. Biointerphases 2012, 7 (1-4), 38.

(82) Wilkie, I. C. Is Muscle Involved in the Mechanical Adaptability of Echinoderm Mutable Collagenous Tissue? J. Exp. Biol. 2002, 205 (2), $159-165$.

(83) Birenheide, R.; Motokawa, T. Motility and Stiffness of Cirri of the Stalked Crinoid Metacrinus Rotundus. In Echinoderm Research; Emson, R. H., Smith, A. B., Campbell, A. C., Eds.;A. A. Balkema: Rotterdam, 1995; pp 91-94.

(84) Birenheide, R.; Motokawa, T. Crinoid Ligaments: Catch and Contractility. Echinoderms San Fr. 1998, 139-144.

(85) Birenheide, R.; Yokoyama, K.; Motokawa, T. Cirri of the Stalked Crinoid Metacrinus Rotundus: Neural Elements and the Effect of Cholinergic Agonists on Mechanical Properties. Proc. R. Soc. London, Ser. B 2000, 267 (1438), 7-16.

(86) Trotter, J. A.; Koob, T. J. Collagen and Proteoglycan in a Sea Urchin Ligament with Mutable Mechanical Properties. Cell Tissue Res. 1989, 258 (3), 527-539.

(87) Wilkie, I. C.; Candia Carnevali, M. D.; Andrietti, F. Microarchitecture and Mechanics of the Sea-Urchin Peristomial Membrane. Bolletino di Zool. 1994, 61 (1), 39-51.

(88) Motokawa, T. Fine Structure of the Dermis of the Body Wall of the Sea Cucumber, Stichopus Chloronotus, a Connective Tissue Which Changes Its Mechanical Properties. Galaxea 1982, 1, 55-64.

(89) Goh, K. L.; Holmes, D. F. Collagenous Extracellular Matrix Biomaterials for Tissue Engineering: Lessons from the Common Sea Urchin Tissue. Int. J. Mol. Sci. 2017, 18 (5), 5.

(90) Shen, Z. L.; Dodge, M. R.; Kahn, H.; Ballarini, R.; Eppell, S. J. Stress-Strain Experiments on Individual Collagen Fibrils. Biophys. J. 2008, 95 (8), 3956-3963.

(91) Shen, Z. L.; Kahn, H.; Ballarini, R.; Eppell, S. J. Viscoelastic Properties of Isolated Collagen Fibrils. Biophys. J. 2011, 100 (12), $3008-3015$.

(92) Thurmond, F. A.; Koob, T. J.; Bowness, J. M.; Trotter, J. A. Partial Biochemical and Immunologic Characterization of Fibrillin Microfibrils from Sea Cucumber Dermis. Connect. Tissue Res. 1997, 36 (3), 211-222.
(93) Trotter, J. A.; Lyons-Levy, G.; Luna, D.; Koob, T. J.; Keene, D. R.; Atkinson, M. A. L. Stiparin: A Glycoprotein from Sea Cucumber Dermis That Aggregates Collagen Fibrils. Matrix Biol. 1996, 15 (2), 99-110.

(94) Koob, T. J.; Koob-Emunds, M. M.; Trotter, J. A. Cell-Derived Stiffening and Plasticizing Factors in Sea Cucumber (Cucumaria Frondosa) Dermis. J. Exp. Biol. 1999, 202 (17), 2291-2301.

(95) Trotter, J. A.; Lyons-Levy, G.; Chino, K.; Koob, T. J.; Keene, D. R.; Atkinson, M. A. L. Collagen Fibril Aggregation-Inhibitor from Sea Cucumber Dermis. Matrix Biol. 1999, 18 (6), 569-578.

(96) Tipper, J. P.; Lyons-Levy, G.; Atkinson, M. A. L.; Trotter, J. A. Purification, Characterization and Cloning of Tensilin, the CollagenFibril Binding and Tissue-Stiffening Factor from Cucumaria Frondosa Dermis. Matrix Biol. 2002, 21 (8), 625-635.

(97) Tricarico, S.; Barbaglio, A.; Burlini, N.; Giacco, L.; Ghilardi, A.; Sugni, M.; Benedetto, C.; Bonasoro, F.; Wilkie, I. C.; Candia Carnevali, M. D. New Insights into the Mutable Collagenous Tissue of Paracentrotus lividus: preliminary results. Zoosymposia 2012, 7, 279-285.

(98) Takehana, Y.; Yamada, A.; Tamori, M.; Motokawa, T. Softenin, a Novel Protein That Softens the Connective Tissue of Sea Cucumbers through Inhibiting Interaction between Collagen Fibrils. PLoS One 2014, 9 (1), 1.

(99) Yu, W. H.; Yu, S. S. C.; Meng, Q.; Brew, K.; Woessner, J. F. TIMP-3 Binds to Sulfated Glycosaminoglycans of the Extracellular Matrix. J. Biol. Chem. 2000, 275 (40), 31226-31232.

(100) Gaino, E.; Pronzato, R. Etude En Microscopie Électronique Du Filament Des Formes Étirées Chez Chondrilla Nucula Schmidt (Porifera, Demospongiae). In Annales des sciences naturelles. Zoologie et biologie animale; Elsevier, 1983; Vol. 5, pp 221-234.

(101) Wilkie, I. C.; Bonasoro, F.; Bavestrello, G.; Cerrano, C.; Candia Carnevali, M. D. Mechanical Properties of the Collagenous Mesohyl of Chondrosia Reniformis: Evidence for Physiological Control. BMIB-Bollettino dei Musei e degli Ist. Biol. 2004, 68, 665-672.

(102) Fassini, D.; Parma, L.; Wilkie, I. C.; Bavestrello, G.; Bonasoro, F.; Candia Carnevali, M. D. Ecophysiology of Mesohyl Creep in the Demosponge Chondrosia Reniformis (Porifera: Chondrosida). J. Exp. Mar. Biol. Ecol. 2012, 428 (C), 24-31.

(103) Fassini, D.; Parma, L.; Lembo, F.; Candia Carnevali, M. D.; Wilkie, I. C.; Bonasoro, F. The Reaction of the Sponge Chondrosia Reniformis to Mechanical Stimulation Is Mediated by the Outer Epithelium and the Release of Stiffening Factor(S). Zoology 2014, 117 (4), 282-291.

(104) Bonasoro, F.; Wilkie, I. C.; Bavestrello, G.; Cerrano, C.; Candia Carnevali, M. D. Dynamic Structure of the Mesohyl in the Sponge Chondrosia Reniformis (Porifera, Demospongiae). Zoomorphology 2001, 121 (2), 109-121.

(105) Sugni, M.; Fassini, D.; Barbaglio, A.; Biressi, A.; Di Benedetto, C.; Tricarico, S.; Bonasoro, F.; Wilkie, I. C.; Candia Carnevali, M. D. Comparing Dynamic Connective Tissue in Echinoderms and Sponges: Morphological and Mechanical Aspects and Environmental Sensitivity. Mar. Environ. Res. 2014, 93 (C), 123-132.

(106) Gravier-Bonnet, N. Cloning and Dispersal by Buoyant Autotomised Hydranths of a Thecate Hydroid (Cnidaria; Hydrozoa). Sci. Mar. 1992, 56 (2), 229-236.

(107) Bavestrello, G.; Puce, S.; Cerrano, C.; Castellano, L.; Arillo, A. Water Movement Activating Fragmentation: A New Dispersal Strategy for Hydractiniid Hydroids. J. Mar. Biol. Assoc. U. K. 2000, 80 (2), 361-362.

(108) Bickell-Page, L. R.; Mackie, G. O. Tentacle Autotomy in the Hydromedusa Aglantha Digitale (Cnidaria): An Ultrastructural and Neurophysiological Analysis. Philos. Trans. R. Soc., B 1991, 331 (1260), 155-170.

(109) Jamilah, B.; Harvinder, K. G. Properties of Gelatins from Skins of Fish - Black Tilapia (Oreochromis Mossambicus) and Red Tilapia (Oreochromis Nilotica). Food Chem. 2002, 77 (1), 81-84.

(110) Grand View Research. Gelatin Market Size, Share \& Trends Analysis Report By Raw Material (Pig Skin, Bovine Hides, Cattle 
Bones), By Function (Thickener, Stabilizer, Gelling Agent), By Application, By Region, And Segment Forecasts, 2020-2027; 2020.

(111) Karim, A. A.; Bhat, R. Fish Gelatin: Properties, Challenges, and Prospects as an Alternative to Mammalian Gelatins. Food Hydrocolloids 2009, 23 (3), 563-576.

(112) Badii, F.; Howell, N. K. Fish Gelatin: Structure, Gelling Properties and Interaction with Egg Albumen Proteins. Food Hydrocolloids 2006, 20 (5), 630-640.

(113) Sharabi, M.; Mandelberg, Y.; Benayahu, D.; Benayahu, Y.; Azem, A.; Haj-Ali, R. A New Class of Bio-Composite Materials of Unique Collagen Fibers. J. Mech. Behav. Biomed. Mater. 2014, 36 (C), $71-81$.

(114) Benayahu, Y.; Benayahu, D.; Kashman, Y.; Rudi, A.; Lanir, Y.; Sella, I.; Raz, E. Coral-Derived Collagen and Methods of Farming Same. U.S. 2013, 2011 (US8552153 B2), No pp. given.

(115) Kiew, P. L.; Mat Don, M. Collagen Extraction from Malaysian Cultured Catfish (Hybrid Clarias Sp.): Kinetics and Optimization of Extraction Conditions Using Response Surface Methodology. ISRN Chem. Eng. 2012, 2012, 1-10.

(116) Osinga, R.; Sidri, M.; Cerig, E.; Gokalp, S.Z. G. M. Sponge Aquaculture Trials in the East-Mediterranean Sea: New Approaches to Earlier Ideas. Open Mar. Biol. J. 2010, 4, 74-81.

(117) Moreira-Silva, J.; Diogo, G. S.; Marques, A. L. P.; Silva, T. H.; Reis, R. L. Marine Collagen Isolation and Processing Envisaging Biomedical Applications. In Biomaterials from Nature for Advanced Devices and Therapies; John Wiley \& Sons, Inc.: Universidade do Minho, Braga, Portugal, 2016; Vol. 64, pp 16-36. DOI: 10.1002/ 9781119126218.ch2.

(118) Barros, A. A.; Aroso, I. M.; Silva, T. H.; Mano, J. F.; Duarte, A. R. C.; Reis, R. L.; Water, R. R.; Dioxide, C.; Reis, R. L. Water and Carbon Dioxide: Green Solvents for the Extraction of Collagen/ Gelatin from Marine Sponges. ACS Sustain. Chem. Eng. 2015, 3 (2), 254-260.

(119) Matsumura, T. Collagen Fibrils of the Sea Cucumber, Stichopus Japonicus: Purification and Morphological Study. Connect. Tissue Res. 1974, 2 (2), 117-125.

(120) Matsumura, T.; Shinmei, M.; Nagai, Y. Disaggregation of Connective Tissue: Preparation of Fibrous Components from Sea Cucumber Body Wall and Calf Skin. J. Biochem. 1973, 73 (1), 155162.

(121) Di Benedetto, C.; Barbaglio, A.; Martinello, T.; Alongi, V.; Fassini, D.; Cullorà, E.; Patruno, M.; Bonasoro, F.; Barbosa, M. A.; Candia Carnevali, M. D.; Sugni, M. Production, Characterization and Biocompatibility of Marine Collagen Matrices from an Alternative and Sustainable Source: The Sea Urchin Paracentrotus Lividus. Mar. Drugs 2014, 12 (9), 4912-4933.

(122) Garrone, R.; Huc, A.; Junqua, S. Fine Structure and Physicochemical Studies on the Collagen of the Marine Sponge Chondrosia Reniformis Nardo. J. Ultrasructure Res. 1975, 52 (2), 261-275.

(123) Deutzmann, R.; Fowler, S.; Zhang, X.; Boone, K.; Dexter, S.; Boot-Handford, R. P.; Rachel, R.; Sarras, J. Molecular, Biochemical and Functional Analysis of a Novel and Developmentally Important Fibrillar Collagen (Hcol-I) in Hydra. Development 2000, 127 (21), 4669-4680.

(124) Birk, D. E.; Nurminskaya, M. V.; Zycband, E. I. Collagen Fibrillogenesis in Situ: Fibril Segments Undergo Post-depositional Modifications Resulting in Linear and Lateral Growth during Matrix Development. Dev. Dyn. 1995, 202 (3), 229-243.

(125) DeVente, J. E.; Lester, G. E.; Trotter, J. A.; Dahners, L. E. Isolation of Intact Collagen Fibrils from Healing Ligament. J. Electron Microsc. 1997, 46 (4), 353-356.

(126) Dahners, L. E.; Lester, G. E.; Caprise, P. The Pentapeptide NKISK Affects Collagen Fibril Interactions in a Vertebrate Tissue. J. Orthop. Res. 2000, 18 (4), 532-536.

(127) Olsen, D.; Yang, C.; Bodo, M.; Chang, R.; Leigh, S.; Baez, J.; Carmichael, D.; Perälä, M.; Hämäläinen, E. R.; Jarvinen, M.; Polarek, J. Recombinant collagen and Gelatin for Drug Delivery. Adv. Drug Delivery Rev. 2003, 55 (12), 1547-1567.
(128) De Bruin, E. C.; Werten, M. W. T.; Laane, C.; De Wolf, F. A. Endogenous Prolyl 4-Hydroxylation in Hansenula Polymorpha and Its Use for the Production of Hydroxylated Recombinant Gelatin. FEMS Yeast Res. 2002, 1 (4), 291-298.

(129) Vuorela, A. Assembly of Human Prolyl 4-Hydroxylase and Type III Collagen in the Yeast Pichia Pastoris: Formation of a Stable Enzyme Tetramer Requires Coexpression with Collagen and Assembly of a Stable Collagen Requires Coexpression with Prolyl 4Hydroxylase. EMBO J. 1997, 16 (22), 6702-6712.

(130) Pozzolini, M.; Scarfi, S.; Mussino, F.; Ferrando, S.; Gallus, L.; Giovine, M. Molecular Cloning, Characterization, and Expression Analysis of a Prolyl 4-Hydroxylase from the Marine Sponge Chondrosia Reniformis. Mar. Biotechnol. 2015, 17 (4), 393-407.

(131) Pozzolini, M.; Scarfi, S.; Mussino, F.; Salis, A.; Damonte, G.; Benatti, U.; Giovine, M. Pichia Pastoris Production of a Prolyl 4Hydroxylase Derived from Chondrosia Reniformis Sponge: A New Biotechnological Tool for the Recombinant Production of Marine Collagen. J. Biotechnol. 2015, 208, 28-36.

(132) Dobson, C. M. Protein Folding and Misfolding. Nature 2003, 426 (6968), 884-890.

(133) Kotch, F. W.; Raines, R. T. Self-Assembly of Synthetic Collagen Triple Helices. Proc. Natl. Acad. Sci. U. S. A. 2006, 103 (9), 3028-3033.

(134) Frank, S.; Kammerer, R. A.; Mechling, D.; Schulthess, T.; Landwehr, R.; Bann, J.; Guo, Y.; Lustig, A.; Bächinger, H. P.; Engel, J. Stabilization of Short Collagen-like Triple Helices by Protein Engineering. J. Mol. Biol. 2001, 308 (5), 1081-1089.

(135) Fleury, C.; Serpentini, A.; Kypriotou, M.; Renard, E.; Galéra, P.; Lebel, J. M. Characterization of a Non-Fibrillar-Related Collagen in the Mollusc Haliotis Tuberculata and Its Biological Activity on Human Dermal Fibroblasts. Mar. Biotechnol. 2011, 13 (5), 10031016.

(136) Proksch, E.; Segger, D.; Degwert, J.; Schunck, M.; Zague, V.; Oesser, S. Oral Supplementation of Specific Collagen Peptides Has Beneficial Effects on Human Skin Physiology: A Double-Blind, Placebo-Controlled Study. Skin Pharmacol. Physiol. 2014, 27 (1), 4755 .

(137) Yamada, S.; Nagaoka, H.; Terajima, M.; Tsuda, N.; Hayashi, Y.; Yamauchi, M. Effects of Fish Collagen Peptides on Collagen PostTranslational Modifications and Mineralization in an Osteoblastic Cell Culture System. Dent. Mater. J. 2013, 32 (1), 88-95.

(138) Felician, F. F.; Xia, C.; Qi, W.; Xu, H. Collagen from Marine Biological Sources and Medical Applications. Chem. Biodiversity 2018, 15 (5), No. e1700557.

(139) Kim, S.-K.; Rao, J.; Pallela, R.; Prakash, G. Prospects of Marine Sponge Collagen and Its Applications in Cosmetology. In Marine Cosmeceuticals; Kim, S. K., Ed.; CRC-Taylor \& Francis Group, 2011; Vol. 20, pp 77-104. DOI: 10.1201/b10120-8.

(140) Pallela, R.; Venkatesan, J.; Janapala, V. R.; Kim, S. K. Biophysicochemical Evaluation of Chitosan-Hydroxyapatite-Marine Sponge Collagen Composite for Bone Tissue Engineering. J. Biomed. Mater. Res. - Part A 2012, 100A (2), 486-495.

(141) Subhan, F.; Ikram, M.; Shehzad, A.; Ghafoor, A. Marine Collagen: An Emerging Player in Biomedical Applications. J. Food Sci. Technol. 2015, 52 (8), 4703-4707.

(142) Jafari, H.; Lista, A.; Siekapen, M. M.; Ghaffari-Bohlouli, P.; Nie, L.; Alimoradi, H.; Shavandi, A. Fish Collagen: Extraction, Characterization, and Applications for Biomaterials Engineering. Polymers 2020, 12 (10), 2230.

(143) Kim, S.-K.; Pallela, R.; Kim, S.-K. Photoprotective and Cosmeceutical Prospects from Marine Origin. Mar. Cosmeceuticals 2011, 67-76

(144) Alves, A.; Marques, A.; Martins, E.; Silva, T. H.; Reis, R. Cosmetic Potential of Marine Fish Skin Collagen. Cosmetics 2017, 4 (4), 39.

(145) Swatschek, D.; Schatton, W.; Kellermann, J.; Müller, W. E. G.; Kreuter, J. Marine Sponge Collagen: Isolation, Characterization and Effects on the Skin Parameters Surface-PH, Moisture and Sebum. Eur. J. Pharm. Biopharm. 2002, 53 (1), 107-113. 
(146) Kim, S. K.; Mendis, E. Bioactive Compounds from Marine Processing Byproducts - A Review. Food Res. Int. 2006, 39 (4), 383393.

(147) Xinrong, P. E. I.; Ruiyue, Y.; Haifeng, Z. Preventive Effects of Marine Collagen Peptide on Learning and Memory in Aged C57BL/ 6J Mice. Food Ferment. Ind. 2009, 35, 26-31.

(148) Xu, Y. J.; Han, X. L.; Li, Y. Effect of Marine Collagen Peptides on Long Bone Development in Growing Rats. J. Sci. Food Agric. 2010, 90 (9), 1485-1491.

(149) Pozzolini, M.; Millo, E.; Oliveri, C.; Mirata, S.; Salis, A.; Damonte, G.; Arkel, M.; Scarfi, S. Elicited ROS Scavenging Activity, Photoprotective, and Wound-Healing Properties of Collagen-Derived Peptides from the Marine Sponge Chondrosia Reniformis. Mar. Drugs 2018, 16 (12), 465.

(150) Malda, J.; Visser, J.; Melchels, F. P.; Jüngst, T.; Hennink, W. E.; Dhert, W. J. A.; Groll, J.; Hutmacher, D. W. 25th Anniversary Article: Engineering Hydrogels for Biofabrication. Adv. Mater. 2013, 25 (36), 5011-5028.

(151) Murphy, S. V.; Atala, A. 3D Bioprinting of Tissues and Organs. Nat. Biotechnol. 2014, 32 (8), 773-785.

(152) Keane, T. J.; Badylak, S. F. Biomaterials for Tissue Engineering Applications. Semin. Pediatr. Surg. 2014, 23 (3), 112118.

(153) Fernandes-Silva, S.; Moreira-Silva, J.; Silva, T. H.; PérezMartín, R. I.; Sotelo, C. G.; Mano, J. F.; Duarte, A. R. C.; Reis, R. L. Porous Hydrogels From Shark Skin Collagen Crosslinked Under Dense Carbon Dioxide Atmosphere. Macromol. Biosci. 2013, 13 (11), $1621-1631$

(154) Manchinasetty, N. V. L.; Oshima, S.; Kikuchi, M. Preparation of Flexible Bone Tissue Scaffold Utilizing Sea Urchin Test and Collagen. J. Mater. Sci.: Mater. Med. 2017, 28 (11), 1-12.

(155) Pozzolini, M.; Scarfi, S.; Gallus, L.; Castellano, M.; Vicini, S.; Cortese, K.; Gagliani, M. C.; Bertolino, M.; Costa, G.; Giovine, M. Production, Characterization and Biocompatibility Evaluation of Collagen Membranes Derived from Marine Sponge Chondrosia Reniformis Nardo, 1847. Mar. Drugs 2018, 16 (4), 111-130.

(156) Swatschek, D.; Schatton, W.; Müller, W. E. G.; Kreuter, J. Microparticles Derived from Marine Sponge Collagen (SCMPs): Preparation, Characterization and Suitability for Dermal Delivery of All-Trans Retinol. Eur. J. Pharm. Biopharm. 2002, 54 (2), 125-133.

(157) Diogo, G. S.; López-Senra, E.; Pirraco, R. P.; Canadas, R. F.; Fernandes, E. M.; Serra, J.; Pérez-Martín, R. I.; Sotelo, C. G.; Marques, A. P.; González, P.; Moreira-Silva, J.; Silva, T. H.; Reis, R. L. Marine Collagen/Apatite Composite Scaffolds Envisaging Hard Tissue Applications. Mar. Drugs 2018, 16 (8), 269.

(158) Wang, J. K.; Yeo, K. P.; Chun, Y. Y.; Tan, T. T. Y.; Tan, N. S.; Angeli, V.; Choong, C. Fish Scale-Derived Collagen Patch Promotes Growth of Blood and Lymphatic Vessels in Vivo. Acta Biomater. 2017, 63, 246-260.

(159) Diogo, G. S.; Carneiro, F.; Freitas-Ribeiro, S.; Sotelo, C. G.; Pérez-Martín, R. I.; Pirraco, R. P.; Reis, R. L.; Silva, T. H. Prionace Glauca Skin Collagen Bioengineered Constructs as a Promising Approach to Trigger Cartilage Regeneration. Mater. Sci. Eng., C 2021, 120, 111587.

(160) Keller, L.; Keller, L. Combined Jellyfish Collagen Type II, Human Stem Cells and Tgf-B3 as a Therapeutic Implant for Cartilage Repair. J. Stem Cell Res. Ther. 2017, 7 (382), 2.

(161) Rigogliuso, S.; Salamone, M.; Barbarino, E.; Barbarino, M.; Nicosia, A.; Ghersi, G. Production of Injectable Marine CollagenBased Hydrogel for the Maintenance of Differentiated Chondrocytes in Tissue Engineering Applications. Int. J. Mol. Sci. 2020, 21 (16), 5798.

(162) Elango, J.; Zhang, J.; Bao, B.; Palaniyandi, K.; Wang, S.; Wenhui, W.; Robinson, J. S. Rheological, Biocompatibility and Osteogenesis Assessment of Fish Collagen Scaffold for Bone Tissue Engineering. Int. J. Biol. Macromol. 2016, 91, 51-59.

(163) Jin, S.; Sun, F.; Zou, Q.; Huang, J.; Zuo, Y.; Li, Y.; Wang, S.; Cheng, L.; Man, Y.; Yang, F.; Li, J. Fish Collagen and Hydroxyapatite Reinforced Poly(Lactide- Co-Glycolide) Fibrous Membrane for
Guided Bone Regeneration. Biomacromolecules 2019, 20 (5), 20582067.

(164) Alkildani, S.; Jung, O.; Barbeck, M. In Vitro Investigation of Jellyfish Collagen as a Tool in Cell Culture and (Bone) Tissue Engineering. Anticancer Res. 2021, 41 (2), 707-717.

(165) Kara, A.; Tamburaci, S.; Tihminlioglu, F.; Havitcioglu, H. Bioactive Fish Scale Incorporated Chitosan Biocomposite Scaffolds for Bone Tissue Engineering. Int. J. Biol. Macromol. 2019, 130, 266279.

(166) Diogo, G. S.; Marques, C. F.; Sotelo, C. G.; Pérez-Martín, R. I.; Pirraco, R. P.; Reis, R. L.; Silva, T. H. Cell-Laden Biomimetically Mineralized Shark-Skin-Collagen-Based 3D Printed Hydrogels for the Engineering of Hard Tissues. ACS Biomater. Sci. Eng. 2020, 6 (6), 3664-3672.

(167) Ferrario, C.; Rusconi, F.; Pulaj, A.; Macchi, R.; Landini, P.; Paroni, M.; Colombo, G.; Martinello, T.; Melotti, L.; Gomiero, C.; Candia Carnevali, M. D.; Bonasoro, F.; Patruno, M.; Sugni, M. From Food Waste to Innovative Biomaterial: Sea Urchin-Derived Collagen for Applications in Skin Regenerative Medicine. Mar. Drugs 2020, 18 (8), 414

(168) Ge, B.; Wang, H.; Li, J.; Liu, H.; Yin, Y.; Zhang, N.; Qin, S. Comprehensive Assessment of Nile Tilapia Skin (Oreochromis Niloticus) Collagen Hydrogels for Wound Dressings. Mar. Drugs 2020, 18 (4), 178.

(169) Zhou, T.; Wang, N.; Xue, Y.; Ding, T.; Liu, X.; Mo, X.; Sun, J. Electrospun Tilapia Collagen Nanofibers Accelerating Wound Healing via Inducing Keratinocytes Proliferation and Differentiation. Colloids Surf., B 2016, 143, 415-422.

(170) Zhou, T.; Sui, B.; Mo, X.; Sun, J. Multifunctional and Biomimetic Fish Collagen/Bioactive Glass Nanofibers: Fabrication, Antibacterial Activity and Inducing Skin Regeneration in Vitro and in Vivo. Int. J. Nanomed. 2017, 12, 3495.

(171) Liu, C.; Sun, J. Hydrolyzed Tilapia Fish Collagen Induces Osteogenic Differentiation of Human Periodontal Ligament Cells. Biomed. Mater. 2015, 10 (6), 065020.

(172) Hu, Z.; Yang, P.; Zhou, C.; Li, S.; Hong, P. Marine Collagen Peptides from the Skin of Nile Tilapia (Oreochromis Niloticus): Characterization and Wound Healing Evaluation. Mar. Drugs 2017, 15 (4), 102.

(173) Felician, F. F.; Yu, R. H.; Li, M. Z.; Li, C. J.; Chen, H. Q.; Jiang, Y.; Tang, T.; Qi, W. Y.; Xu, H. M. The Wound Healing Potential of Collagen Peptides Derived from the Jellyfish Rhopilema Esculentum. Chin. J. Traumatol. 2019, 22 (1), 12-20.

(174) Sanz, B.; Sanchez, A. A.; Tangey, B.; Gilmore, K.; Yue, Z.; Liu, X.; Wallace, G. Light Cross-Linkable Marine Collagen for Coaxial Printing of a 3D Model of Neuromuscular Junction Formation. Biomedicines 2021, 9 (1), 16.

(175) Nguyen, C. T.; Vu, M. Q.; Phan, T. T.; Vu, T. Q.; Vo, Q. A.; Bach, G. L.; Thai, H. Novel PH-Sensitive Hydrogel Beads Based on Carrageenan and Fish Scale Collagen for Allopurinol Drug Delivery. J. Polym. Environ. 2020, 28 (6), 1795-1810.

(176) Moreira da Silva, J. C. R.; Carlos, G. S. D.; Prata, M. de S. e. S. B.; Henriques da Silva, T. J. Q. L.; Marques, A. M. P.; Goncalves dos Reis, R. L.; Cerqueira, M. T. Marine-Sponge Type IV Collagen Membranes Its Production and Biomedical Applications Thereof., 2015, No. WO2015186118 A1.

(177) Nandi, S. K.; Kundu, B.; Mahato, A.; Thakur, N. L.; Joardar, S. N.; Mandal, B. B. In Vitro and in Vivo Evaluation of the Marine Sponge Skeleton as a Bone Mimicking Biomaterial. Integr. Biol. (United Kingdom) 2015, 7 (2), 250-262.

(178) Lin, Z.; Solomon, K. L.; Zhang, X.; Pavlos, N. J.; Abel, T.; Willers, C.; Dai, K.; Xu, J.; Zheng, Q.; Zheng, M. In Vitro Evaluation of Natural Marine Sponge Collagen as a Scaffold for Bone Tissue Engineering. Int. J. Biol. Sci. 2011, 7 (7), 968-977.

(179) Parisi, J. R.; Fernandes, K. R.; Avanzi, I. R.; Dorileo, B. P.; Santana, A. F.; Andrade, A. L.; Gabbai-Armelin, P. R.; Fortulan, C. A.; Trichês, E. S.; Granito, R. N.; Renno, A. C. M. Incorporation of Collagen from Marine Sponges (Spongin) into Hydroxyapatite 
Samples: Characterization and In Vitro Biological Evaluation. Mar. Biotechnol. 2019, 21 (1), 30-37.

(180) Widdowson, J. P.; Picton, A. J.; Vince, V.; Wright, C. J.; Mearns-Spragg, A. In Vivo Comparison of Jellyfish and Bovine Collagen Sponges as Prototype Medical Devices. J. Biomed. Mater. Res., Part B 2018, 106 (4), 1524-1533.

(181) Langasco, R.; Cadeddu, B.; Formato, M.; Lepedda, A. J.; Cossu, M.; Giunchedi, P.; Pronzato, R.; Rassu, G.; Manconi, R.; Gavini, E. Natural Collagenic Skeleton of Marine Sponges in Pharmaceutics: Innovative Biomaterial for Topical Drug Delivery. Mater. Sci. Eng., C 2017, 70, 710-720.

(182) Azizur Rahman, M. Collagen of Extracellular Matrix from Marine Invertebrates and Its Medical Applications. Mar. Drugs 2019, 17 (2), 112-118.

(183) Subhan, F.; Hussain, Z.; Tauseef, I.; Shehzad, A.; Wahid, F. A Review on Recent Advances and Applications of Fish Collagen. Crit. Rev. Food Sci. Nutr. 2021, 61 (6), 1027-1037.

(184) Weadock, K. S.; Miller, E. J.; Bellincampi, L. D.; Zawadsky, J. P.; Dunn, M. G. Physical Crosslinking of Collagen Fibers: Comparison of Ultraviolet Irradiation and Dehydrothermal Treatment. J. Biomed. Mater. Res. 1995, 29 (11), 1373-1379.

(185) Dewavrin, J.-Y. Y.; Hamzavi, N.; Shim, V. P. W. W.; Raghunath, M. Tuning the Architecture of Three-Dimensional Collagen Hydrogels by Physiological Macromolecular Crowding. Acta Biomater. 2014, 10 (10), 4351-4359.

(186) Chandran, P. L.; Paik, D. C.; Holmes, J. W. Structural Mechanism for Alteration of Collagen Gel Mechanics by Glutaraldehyde Crosslinking. Connect. Tissue Res. 2012, 53 (4), 285-297.

(187) Gough, J. E.; Scotchford, C. A.; Downes, S. Cytotoxicity of Glutaraldehyde Crosslinked Collagen/Poly(Vinyl Alcohol) Films Is by the Mechanism of Apoptosis. J. Biomed. Mater. Res. 2002, 61 (1), 121-130.

(188) Osborne, C.; Barbenel, J.; Smith, D.; Savakis, M.; Grant, M. Investigation into the Tensile Properties of Collagen/Chondroitin-6Sulphate Gels: The Effect of Crosslinking Agents and Diamines. Med. Biol. Eng. Comput. 1998, 36 (1), 129-134.

(189) Zeugolis, D.; Paul, G.; Attenburrow, G. Cross-Linking of Extruded Collagen Fibers-A Biomimetic Three-Dimensional Scaffold for Tissue Engineering Applications. J. Biomed. Mater. Res., Part A 2009, 89, 895-908.

(190) Walters, B. D.; Stegemann, J. P. Strategies for Directing the Structure and Function of Three-Dimensional Collagen Biomaterials across Length Scales. Acta Biomater. 2014, 10 (4), 1488-1501.

(191) Sundararaghavan, H. G.; Monteiro, G. A.; Lapin, N. A.; Chabal, Y. J.; Miksan, J. R.; Shreiber, D. I. Genipin-Induced Changes in Collagen Gels: Correlation of Mechanical Properties to Fluorescence. J. Biomed. Mater. Res. - Part A 2008, 87 (2), 308-320.

(192) Berthod, F.; Saintigny, G.; Chretien, F.; Hayek, D.; Collombel, C.; Damour, O. Optimization of Thickness, Pore Size and Mechanical Properties of a Biomaterial Designed for Deep Burn Coverage. Clin. Mater. 1994, 15 (4), 259-265.

(193) Berthod, F.; Hayek, D.; Damour, O.; Collombel, C. Collagen Synthesis by Fibroblasts Cultured within a Collagen Sponge. Biomaterials 1993, 14 (10), 749-754.

(194) Orban, J. M.; Wilson, L. B.; Kofroth, J. A.; El-Kurdi, M. S.; Maul, T. M.; Vorp, D. A. Crosslinking of Collagen Gels by Transglutaminase. J. Biomed. Mater. Res. 2004, 68 (4), 756-762.

(195) Wollensak, G.; Spoerl, E.; Seiler, T. Riboflavin/Ultraviolet-AInduced Collagen Crosslinking for the Treatment of Keratoconus. Am. J. Ophthalmol. 2003, 135 (5), 620-627.

(196) Kimura, S.; Omura, Y.; Ishida, M.; Shirai, H. Molecular Characterization of Fibrillar Collagen from the Body Wall of Starfish Asterias Amurensis. Comp. Biochem. Physiol. - Part B Biochem. 1993, 104 (4), 663-668.

(197) Thurmond, F. A.; Trotter, J. A. Native Collagen Fibrils from Echinoderms Are Molecularly Bipolar. J. Mol. Biol. 1994, 235 (1), 73-79.
(198) Nagai, T.; Suzuki, N. Partial Characterization of Collagen from Purple Sea Urchin (Anthocidaris Crassispina) Test. Int. J. Food Sci. Technol. 2000, 35 (5), 497-501.

(199) Zhong, M.; Chen, T.; Hu, C.; Ren, C. Isolation and Characterization of Collagen from the Body Wall of Sea Cucumber Stichopus Monotuberculatus. J. Food Sci. 2015, 80 (4), C671-C679.

(200) Ferrario, C.; Leggio, L.; Leone, R.; Di Benedetto, C.; Guidetti, L.; Coccè, V.; Ascagni, M.; Bonasoro, F.; La Porta, C. A. M.; Candia Carnevali, M. D.; Sugni, M. Marine-Derived Collagen Biomaterials from Echinoderm Connective Tissues. Mar. Environ. Res. 2017, 128, 46-57.

(201) Tan, C. C.; Karim, A. A.; Latiff, A. A.; Gan, C. Y.; Ghazali, F. C.; Extraction, G. F. Extraction and Characterization of PepsinSolubilized Collagen from the Body Wall of Crown-of-Thorns Starfish (Acanthaster Planci). Int. Food Res. J. 2013, 20 (6), 3013-3020.

(202) Rivera-Posada, J.; Pratchett, M. S.; Aguilar, C.; Grand, A.; Caballes, C. F. Bile Salts and the Single-Shot Lethal Injection Method for Killing Crown-of-Thorns Sea Stars (Acanthaster Planci). Ocean Coast. Manag. 2014, 102 (PA), 383-390.

(203) Slezak, M. The Starfish Terminator. New Sci. 2016, 229 (3056), 35-37.

(204) Purcell, S. W.; Hair, C. A.; Mills, D. J. Sea Cucumber Culture, Farming and Sea Ranching in the Tropics: Progress, Problems and Opportunities. Aquaculture 2012, 368-369, 68-81.

(205) Namukose, M.; Msuya, F. E.; Ferse, S. C. A.; Slater, M. J.; Kunzmann, A. Growth Performance of the Sea Cucumber Holothuria Scabra and the Seaweed Eucheuma Denticulatum: Integrated Mariculture and Effects on Sediment Organic Characteristics. Aquac. Environ. Interact. 2016, 8, 179-189.

(206) Omura, Y.; Urano, N.; Kimura, S. Occurrence of Fibrillar Collagen with Structure of (A1)2 A2 in the Test of Sea Urchin Asthenosoma Ijimai. Comp. Biochem. Physiol., Part B: Biochem. Mol. Biol. 1996, 115 (1), 63-68.

(207) Barbaglio, A.; Tricarico, S.; Di Benedetto, C.; Fassini, D.; Lima, A. P.; Ribeiro, A. R.; Ribeiro, C. C.; Sugni, M.; Bonasoro, F.; Wilkie, I. C.; Barbosa, M.; Candia Carnevali, M. D. The Smart Connective Tissue of Echinoderms: A Materializing Promise for Biotech Applications. In Cahiers de Biologie Marine;2013, 54, 713720.

(208) Fang, M.; Holl, M. M. B. Variation in Type I Collagen Fibril Nanomorphology: The Significance and Origin. Bonekey Rep. 2013, 2, 394.

(209) Zeugolis, D. I.; Khew, S. T.; Yew, E. S. Y.; Ekaputra, A. K.; Tong, Y. W.; Yung, L. Y. L.; Hutmacher, D. W.; Sheppard, C.; Raghunath, M. Electro-Spinning of Pure Collagen Nano-Fibres - Just an Expensive Way to Make Gelatin? Biomaterials 2008, 29 (15), $2293-2305$

(210) Kariya, Y.; Watabe, S.; Kyogashima, M.; Ishihara, M.; Ishii, T. Structure of Fucose Branches in the Glycosaminoglycan from the Body Wall of the Sea Cucumber Stichopus Japonicus. Carbohydr. Res. 1997, 297 (3), 273-279.

(211) Trotter, J. A.; Tipper, J.; Lyons-Levy, G.; Chino, K.; Heuer, A. H.; Liu, Z.; Mrksich, M.; Hodneland, C.; Dillmore, W. S.; Koob, T. J.; Koob-Emunds, M. M.; Kadler, K.; Holmes, D. Towards a Fibrous Composite with Dynamically Controlled Stiffness: Lessons from Echinoderms. Biochem. Soc. Trans. 2000, 28 (4), 357-362.

(212) Capadona, J. R.; Shanmuganathan, K.; Tyler, D. J.; Rowan, S. J.; Weder, C. Stimuli-Responsive Polymer Nanocomposites Inspired by the Sea Cucumber Dermis. Science 2008, 319 (5868), 1370-1374.

(213) Benayahu, D.; Sharabi, M.; Pomeraniec, L.; Awad, L.; Haj-Ali, R.; Benayahu, Y. Unique Collagen Fibers for Biomedical Applications. Mar. Drugs 2018, 16 (4), 102.

(214) Benayahu, D.; Pomeraniec, L.; Shemesh, S.; Heller, S.; Rosenthal, Y.; Rath-Wolfson, L.; Benayahu, Y. Biocompatibility of a Marine Collagen-Based Scaffold in Vitro and in Vivo. Mar. Drugs 2020, 18 (8), 420.

(215) Yu, D.; Chi, C. F.; Wang, B.; Ding, G. F.; Li, Z. R. Characterization of Acid-and Pepsin-Soluble Collagens from Spines 
and Skulls of Skipjack Tuna (Katsuwonus Pelamis). Chin. J. Nat. Med. 2014, 12 (9), 712-720.

(216) Yan, M.; Li, B.; Zhao, X.; Ren, G.; Zhuang, Y.; Hou, H.; Zhang, X.; Chen, L.; Fan, Y. Characterization of Acid-Soluble Collagen from the Skin of Walleye Pollock (Theragra Chalcogramma). Food Chem. 2008, 107 (4), 1581-1586.

(217) Zelechowska, E.; Sadowska, M.; Turk, M. Isolation and Some Properties of Collagen from the Backbone of Baltic Cod (Gadus Morhua). Food Hydrocolloids 2010, 24 (4), 325-329.

(218) Kaewdang, O.; Benjakul, S.; Kaewmanee, T.; Kishimura, H. Characteristics of Collagens from the Swim Bladders of Yellowfin Tuna (Thunnus Albacares). Food Chem. 2014, 155, 264-270.

(219) Noitup, P.; Garnjanagoonchorn, W.; Morrissey, M. T.; Ganjanagoonchorn, W.; Morrissey, M. T. Fish Skin Type I Collagen: Characteristic Comparison of Albacore Tuna (Thunnus Alalunga) and Silver-Line Grunt (Pomadasys Kaakan). J. Aquat. Food Prod. Technol. 2005, 14 (1), 17-28.

(220) Nalinanon, S.; Benjakul, S.; Kishimura, H. Collagens from the Skin of Arabesque Greenling (Pleurogrammus Azonus) Solubilized with the Aid of Acetic Acid and Pepsin from Albacore Tuna (Thunnus Alalunga) Stomach. J. Sci. Food Agric. 2010, 90 (9), 14921500.

(221) Senaratne, L. S.; Park, P. J.; Kim, S. K.; Isolation, K. S. Isolation and Characterization of Collagen from Brown Backed Toadfish (Lagocephalus Gloveri) Skin. Bioresour. Technol. 2006, 97 (2), 191-197.

(222) Nagai, T.; Araki, Y.; Suzuki, N. Collagen of the Skin of Ocellate Puffer Fish (Takifugu Rubripes). Food Chem. 2002, 78 (2), 173-177.

(223) Nalinanon, S.; Benjakul, S.; Visessanguan, W.; Kishimura, H. Use of Pepsin for Collagen Extraction from the Skin of Bigeye Snapper (Priacanthus Tayenus). Food Chem. 2007, 104 (2), 593601.

(224) Ogawa, M.; Portier, R. J.; Moody, M. W.; Bell, J.; Schexnayder, M. A.; Losso, J. N. Biochemical Properties of Bone and Scale Collagens Isolated from the Subtropical Fish Black Drum (Pogonia Cromis) and Sheepshead Seabream (Archosargus Probatocephalus). Food Chem. 2004, 88 (4), 495-501.

(225) Ciarlo, A. S.; Paredi, M. E.; Fraga, A. N. Isolation of Soluble Collagen from Hake Skin (Merluccius Hubbsi). J. Aquat. Food Prod. Technol. 1997, 6 (1), 65-77.

(226) Wang, L.; An, X.; Xin, Z.; Zhao, L.; Isolation, H. Q.; Hu, Q. Isolation and Characterization of Collagen from the Skin of Deep-Sea Redfish (Sebastes Mentella). J. Food Sci. 2007, 72 (8), E450-E455.

(227) Jongjareonrak, A.; Benjakul, S.; Visessanguan, W.; Nagai, T.; Tanaka, M.; Isolation, T. M. Isolation and Characterisation of Acid and Pepsin-Solubilised Collagens from the Skin of Brownstripe Red Snapper (Lutjanus Vitta). Food Chem. 2005, 93 (3), 475-484.

(228) Matmaroh, K.; Benjakul, S.; Prodpran, T.; Encarnacion, A. B.; Kishimura, H. Characteristics of Acid Soluble Collagen and Pepsin Soluble Collagen from Scale of Spotted Golden Goatfish (Parupeneus Heptacanthus). Food Chem. 2011, 129 (3), 1179-1186.

(229) Veeruraj, A.; Arumugam, M.; Balasubramanian, T. Isolation and Characterization of Thermostable Collagen from the Marine EelFish (Evenchelys Macrura). Process Biochem. 2013, 48 (10), 15921602.

(230) Ahmad, M.; Benjakul, S. Extraction and Characterisation of Pepsin-Solubilised Collagen from the Skin of Unicorn Leatherjacket (Aluterus Monocerous). Food Chem. 2010, 120 (3), 817-824.

(231) Yunoki, S.; Nagai, N.; Suzuki, T.; Munekata, M. Novel Biomaterial from Reinforced Salmon Collagen Gel Prepared by Fibril Formation and Cross-Linking. J. Biosci. Bioeng. 2004, 98 (1), 40-47. (232) Li, J.; Wang, M.; Qiao, Y.; Tian, Y.; Liu, J.; Qin, S.; Wu, W. Extraction and Characterization of Type I Collagen from Skin of Tilapia (Oreochromis Niloticus) and Its Potential Application in Biomedical Scaffold Material for Tissue Engineering. Process Biochem. 2018, 74, 156-163.

(233) Kittiphattanabawon, P.; Benjakul, S.; Visessanguan, W.; Shahidi, F. Isolation and Characterization of Collagen from the
Cartilages of Brownbanded Bamboo Shark (Chiloscyllium Punctatum) and Blacktip Shark (Carcharhinus Limbatus). LWT - Food Sci. Technol. 2010, 43 (5), 792-800.

(234) Hwang, J. H.; Mizuta, S.; Yokoyama, Y.; Yoshinaka, R. Purification and Characterization of Molecular Species of Collagen in the Skin of Skate (Raja Kenojei). Food Chem. 2007, 100 (3), 921925 .

(235) Jeevithan, E.; Bao, B.; Bu, Y.; Zhou, Y.; Zhao, Q.; Wu, W. Type II Collagen and Gelatin from Silvertip Shark (Carcharhinus Albimarginatus) Cartilage: Isolation, Purification, Physicochemical and Antioxidant Properties. Mar. Drugs 2014, 12 (7), 3852-3873.

(236) Cui, F. X.; Xue, C. H.; Li, Z. J.; Zhang, Y. Q.; Dong, P.; Fu, X. Y.; Gao, X. Characterization and Subunit Composition of Collagen from the Body Wall of Sea Cucumber Stichopus Japonicus. Food Chem. 2007, 100 (3), 1120-1125.

(237) Abedin, M. Z.; Karim, A. A.; Ahmed, F.; Latiff, A. A.; Gan, C. Y.; Che Ghazali, F.; Islam Sarker, M. Z. Isolation and Characterization of Pepsin-Solubilized Collagen From the Integument of Sea Cucumber (Stichopus Vastus). J. Sci. Food Agric. 2013, 93 (5), $1083-1088$

(238) Adibzadeh, N.; Aminzadeh, S.; Jamili, S.; Karkhane, A. A.; Farrokhi, N. Purification and Characterization of Pepsin-Solubilized Collagen from Skin of Sea Cucumber Holothuria Parva. Appl. Biochem. Biotechnol. 2014, 173 (1), 143-154.

(239) Siddiqui, Y. D.; Arief, E. M.; Yusoff, A.; Suzina, A. H.; Abdullah, S. Y. Isolation of Pepsin-Solubilized Collagen (PSC) from Crude Collagen Extracted from Body Wall of Sea Cucumber (Bohadschia Spp.). Int. J. Pharm. Pharm. Sci. 2013, 5 (SUPPL. 2), 555-559.

(240) Shimizu, K.; Amemiya, S.; Yoshizato, K. Biochemical and Immunological Characterization of Collagen Molecules from Echinothurioid Sea Urchin Asthenosoma Ijimai. Biochim. Biophys. Acta (BBA)/Protein Struct. Mol. 1990, 1038 (1), 39-46.

(241) Liu, Z.; Oliveira, A. C. M.; Purification, S. Y.; Su, Y. C. Purification and Characterization of Pepsin-Solubilized Collagen from Skin and Connective Tissue of Giant Red Sea Cucumber (Parastichopus Californicus). J. Agric. Food Chem. 2010, 58 (2), 12701274.

(242) Nagai, T.; Yamashita, E.; Taniguchi, K.; Kanamori, N.; Suzuki, N. Isolation and Characterisation of Collagen from the Outer Skin Waste Material of Cuttlefish (Sepia Lycidas). Food Chem. 2001, 72 (4), 425-429.

(243) Nagai, T.; Suzuki, N. Preparation and Partial Characterization of Collagen from Paper Nautilus (Argonauta Argo, Linnaeus) Outer Skin. Food Chem. 2002, 76 (2), 149-153.

(244) Nam, K. A.; You, S. G.; Kim, S. M. Molecular and Physical Characteristics of Squid (Todarodes Pacificus) Skin Collagens and Biological Properties of Their Enzymatic Hydrolysates. J. Food Sci. 2008, 73 (4), C249-C255.

(245) Nagai, T.; Nagamori, K.; Yamashita, E.; Suzuki, N. Collagen of Octopus Callistoctopus Arakawai Arm. Int. J. Food Sci. Technol. 2002, 37 (3), 285-289.

(246) Coelho, R. C. G.; Marques, A. L. P.; Oliveira, S. M.; Diogo, G. S.; Pirraco, R. P.; Moreira-Silva, J.; Xavier, J. C.; Reis, R. L.; Silva, T. H.; Mano, J. F. Extraction and Characterization of Collagen from Antarctic and Sub-Antarctic Squid and Its Potential Application in Hybrid Scaffolds for Tissue Engineering. Mater. Sci. Eng., C 2017, 78, 787-795.

(247) Uriarte-Montoya, M. H.; Arias-Moscoso, J. L.; PlascenciaJatomea, M.; Santacruz-Ortega, H.; Rouzaud-Sández, O.; CardenasLopez, J. L.; Marquez-Rios, E.; Ezquerra-Brauer, J. M. Jumbo Squid (Dosidicus Gigas) Mantle Collagen: Extraction, Characterization, and Potential Application in the Preparation of Chitosan-Collagen Biofilms. Bioresour. Technol. 2010, 101 (11), 4212-4219.

(248) Sivakumar, P.; Suguna, L.; Chandrakasan, G. Molecular Species of Collagen in the Intramuscular Connective Tissues of the Marine Crab, Scylla Serrata. Comp. Biochem. Physiol., Part B: Biochem. Mol. Biol. 2000, 125 (4), 555-562. 
(249) Sivakumar, P.; Suguna, L.; Chandrakasan, G. Purification and Partial Characterization of a Type V like Collagen from the Muscle of Marine Prawn, Penaeus Indicus. J. Biosci. 1997, 22 (2), 131-141.

(250) Gaill, F.; Mann, K.; Wiedemann, H.; Engel, J.; Timpl, R. Structural Comparison of Cuticle and Interstitial Collagens from Annelids Living in Shallow Sea-Water and at Deep-Sea Hydrothermal Vents. J. Mol. Biol. 1995, 246 (2), 284-294.

(251) Nagai, T.; Worawattanamateekul, W.; Suzuki, N.; Nakamura, T.; Ito, T.; Fujiki, K.; Nakao, M.; Yano, T. Isolation and Characterization of Collagen from Rhizostomous Jellyfish (Rhopilema Asamushi). Food Chem. 2000, 70 (2), 205-208.

(252) Krishnan, S.; Perumal, P. Preparation and Biomedical Characterization of Jellyfish (Chrysaora Quinquecirrha) Collagen from Southeast Coast of India. Int. J. Pharm. Pharm. Sci. 2013, 5 (3), 698-701.

(253) Zhang, J.; Duan, R.; Huang, L.; Song, Y.; Regenstein, J. M. Characterisation of Acid-Soluble and Pepsin-Solubilised Collagen from Jellyfish (Cyanea Nozakii Kishinouye). Food Chem. 2014, 150, $22-26$.

(254) Addad, S.; Exposito, J. Y.; Faye, C.; Ricard-Blum, S.; Lethias, C. Isolation, Characterization and Biological Evaluation of Jellyfish Collagen for Use in Biomedical Applications. Mar. Drugs 2011, 9 (6), 967-983.

(255) Rastian, Z.; Pütz, S.; Wang, Y. J.; Kumar, S.; Fleissner, F.; Weidner, T.; Parekh, S. H. Type I Collagen from Jellyfish Catostylus Mosaicus for Biomaterial Applications. ACS Biomater. Sci. Eng. 2018, 4 (6), 2115-2125.

(256) Song, E.; Yeon Kim, S.; Chun, T.; Byun, H. J.; Lee, Y. M. Collagen Scaffolds Derived from a Marine Source and Their Biocompatibility. Biomaterials 2006, 27 (15), 2951-2961.

(257) Pallela, R.; Bojja, S.; Biochemical, J. V.; Janapala, V. R. Biochemical and Biophysical Characterization of Collagens of Marine Sponge, Ircinia Fusca (Porifera: Demospongiae: Irciniidae). Int. J. Biol. Macromol. 2011, 49 (1), 85-92. 